2018

\title{
School Desegregation 2.0: What is Required to Finally Integrate America's Public Schools
}

Jim Hilbert

Mitchell Hamline School of Law, jim.hilbert@mitchellhamline.edu

Publication Information

16 Northwestern Journal of Human Rights 92 (2018)

First published by Northwestern Journal of Human Rights, Volume 16, Issue 1

\section{Repository Citation}

Hilbert, Jim, "School Desegregation 2.0: What is Required to Finally Integrate America's Public Schools" (2018). Faculty Scholarship. 442.

https://open.mitchellhamline.edu/facsch/442 


\title{
School Desegregation 2.0: What is Required to Finally Integrate America's Public Schools
}

\begin{abstract}
More than ten years have passed since the United States Supreme Court last addressed school desegregation. In its abbreviated tenure in the decades following Brown v. Board of Education, school desegregation was successful in many respects. Longstanding policies of state-sponsored educational apartheid eventually ended. A great many school buildings became more diverse. Countless students of color gained access to improved academic opportunities and better life outcomes. A consensus formed around the positive impacts that desegregation could have on both students of color and white students. When courts retreated from upholding desegregation policies, many communities developed their own voluntary plans, some of which even continue today.
\end{abstract}

Yet by any measure, the original goals of Brown remain unfulfilled. Desegregation has nearly disappeared from the lexicon of educational reform, and America's schools are becoming dramatically more segregated. While the courts are certainly to blame, the design and implementation of desegregation itself contributed to its own downfall. Desegregation has almost exclusively focused on balancing the number of students of different races in public schools, and nothing more. School district plans for addressing segregation often passed constitutional muster by merely moving students of color into previously all-white schools.

As a result, schools became desegregated but were never fully integrated. Integration, as compared to desegregation, naturally requires the removal of the structures of segregation, but it also seeks to address more than just diversity in terms of numbers. Actual integration requires going beyond demographics, to include reforming the classroom and curriculum, and diversifying the teaching ranks. It breaks through school district boundaries to forge metropolitan-wide solutions. It requires changes beyond education, connecting housing and education policy. And because of the most recent Supreme Court decision, it requires using other metrics, in addition to race, to promote broad diversity in the public schools.

After providing a brief overview of desegregation's main achievements and its largest setbacks, this article examines successful desegregation programs from around the country and describes what has made these efforts worthwhile and legally sound. It then makes policy recommendations as to how to strengthen desegregation, such as avoiding the legal pitfalls of recent Supreme Court cases through geographic basedsolutions, increasing diversity of our teaching ranks, and linking housing and education policy.

\section{Keywords}

Desegregation, Integration, Education law, School segregation, Race-conscious remedies, Concentrated poverty

\author{
Disciplines \\ Civil Rights and Discrimination | Education Law
}

Comments

First published by Northwestern Journal of Human Rights, Volume 16, Issue 1 


\title{
School Desegregation 2.0: What is Required to Finally Integrate America's Public Schools
}

\section{Jim Hilbert}

\author{
INTRODUCTION
}

More than ten years have passed since the United States Supreme Court last addressed school desegregation. ${ }^{1}$ In its most recent decision on the subject, ${ }^{2}$ the Court delivered what many initially considered to be a final blow to an education policy that the Court itself had created five decades earlier. ${ }^{3}$ Back then, in Brown v. Board of Education, ${ }^{4}$ the Court famously declared that schools separated by race were inherently unconstitutional. ${ }^{5}$ Subsequent lower courts required school districts to "desegregate" public schools. ${ }^{6}$ In the last few decades, however, the Court has largely abandoned efforts to dismantle school segregation. ${ }^{7}$

\footnotetext{
* Associate Professor of Law at Mitchell Hamline School of Law; Chair of the St. Paul NAACP Education Committee. I would like to thank Henna Hussain, Caitlin Schweiger, Rebecca Noothed, and Daniel McCourtney for their helpful research assistance.

${ }^{1}$ More than ten years had passed prior to that decision, as well. Even the mere mentioning of the Brown v. Board of Education decision had become rare. See Mark A. Graber, The Price of Fame: Brown as Celebrity, 69 OHIO ST. L.J. 939 (2008) (reporting that, prior to 2007, the Rehnquist and Roberts Supreme Courts rarely cited Brown for any significant legal proposition, and almost never did so after George W. Bush took office in 2001).

${ }^{2}$ Parents Involved in Cmty. Sch. v. Seattle School Dist. No. 1, 551 U.S. 701 (2007).

${ }^{3}$ See Don Corbett, Stunted Growth: Assessing the Stagnant Enrollment of African-American Students at the Nation's Law Schools, 18 TEMP. POL. \& CIV. RTS. L. REV. 177, 193-94 (2008) (observing that Parents Involved "produced waves of hand-wringing from both legal observers and civil rights commentators, who claimed that Roberts' opinion marked the affirmative abandonment of the principles espoused in Brown, and the end of substantive school desegregation" and citing, as an example, Erwin Chemerinsky \& Charles Clotfelter, Op-Ed., The Death of Desegregation, Raleigh News \& Observer, July 3, 2007, at A11).

347 U.S 483, 495 (1954).

${ }^{5} I d$. ("[I]n the field of public education the doctrine of 'separate but equal' has no place. Separate educational facilities are inherently unequal.").

${ }^{6}$ For example, in the second Brown decision, which focused on remedy, the Court squarely placed the responsibility of creating specific desegregation orders on district courts, because "their proximity to local conditions" made lower courts best-suited to rule on which particular remedies would be most appropriate. Brown v. Board of Educ. ("Brown II"), 349 U.S. 294, 299 (1955).

${ }^{7}$ The Supreme Court's most recent decision strengthening desegregation policies was over 40 years ago. See GARY Orfield \& Erica Frankenberg, C.R. Project, Brown at 60: Great Progress, A Long Retreat And an UNCERTAIN FUTURE 4 (2014) (explaining that the last case was in 1973). Of course, the federal government also withdrew its support for desegregation around that same time. For example, the last major Congressional action supporting desegregation in schools was in 1972. Id.
} 
Despite its abbreviated tenure, school desegregation was successful in many respects. ${ }^{8}$ Longstanding policies of state-sponsored educational apartheid eventually ended. ${ }^{9}$ A great many school buildings became more diverse. ${ }^{10}$ Countless students of color gained access to improved academic opportunities and better life outcomes. ${ }^{11}$ A consensus formed around the positive impacts that desegregation could have on both students of color and white students. ${ }^{12}$ When courts retreated from upholding desegregation policies, many communities developed their own voluntary plans, some of which continue today. ${ }^{13}$

Yet by any measure, the original goals of Brown remain unfulfilled. ${ }^{14}$ Desegregation has nearly disappeared from the lexicon of educational reform, ${ }^{15}$ and America's schools are becoming dramatically more segregated. ${ }^{16}$ While the courts are certainly to blame, ${ }^{17}$ the design and implementation of desegregation itself contributed to its own downfall. Desegregation has almost exclusively focused on balancing the number of students of different races in public schools, and nothing more. ${ }^{18}$ School district plans for addressing segregation often passed

\footnotetext{
${ }^{8}$ See infra notes 28-47 and accompanying text (detailing the impact of school desegregation on student achievement and life outcomes).

${ }^{9}$ Richard Kluger, Simple Justice: The History of BROWN $V$. BOARD OF EDUCATION AND BlaCk America's STRUGGLE FOR EQUALITY 780 (2004) ("At the least, we can say it brought to an end more than three centuries of an officially sanctioned mind-set embracing white supremacy[.]").

${ }^{10}$ Of course, more than just lawyers and federal courts desegregated schools. Implementation of The Civil Rights Act of 1964 may have made a bigger impact than the early court decisions. See Gary Orfield, The 1964 Civil Rights Act and American Education, in LEGACIES OF THE 1964 CIVIL RIGHTS ACT 89, 101 (Bernard Grofman ed., 2000) ("The first year of enforcement of the 1964 law showed that administrative agencies had been able to reach many more school districts and create much more desegregation in one year than had all the lawyers and federal courts of the previous decade.").

${ }^{11}$ See, e.g., Roslyn Arlin Mickelson \& Martha Bottia, Integrated Education and Mathematics Outcomes: A Synthesis of Social Science Research, 88 N.C. L. REV. 993, 1028 (2010) (finding that the "quantity and quality of the studies that discuss the effects of racial composition collectively offer strong evidence that racially ... diverse schools foster higher performance.").

${ }^{12}$ See, e.g., Thomas F. Pettigrew \& Linda R. Tropp, A Meta-Analytic Test of Intergroup Contact Theory, $90 \mathrm{~J}$. PERSONALITY \& SOC. PSYCHOL. 751, 766 (2005) (concluding from a meta-analysis of 515 studies that interracial prejudice diminishes with intergroup racial contact).

${ }^{13}$ See infra notes 83-151 and accompanying text (describing some of the most effective desegregation plans from across the country).

${ }^{14}$ See infra note 217 and accompanying text (discussing how the original goals of the Brown litigation have not been met).

${ }^{15}$ Danielle Holley-Walker, A New Era for Desegregation, 28 GA. ST. U. L. REV. 423, 423-24 (2012)

("Desegregation is a term from a bygone era . . a historical term, a term from the past.").

${ }^{16}$ The number of segregated schools, as measured by the federal government, more than doubled since just 2000. See U.S. GOV'T ACCOUNTABILITy OfFiCE, GAO-16-345, K-12 EduCATION: BETTER USE OF INFORMATION COULD HELP AGENCIES IDENTIFY DISPARITIES AND ADDRESS RACIAL DISCRIMINATION 12 (2016), available at http://www.gao.gov/assets/680/676745.pdf ("Specifically, according to our analysis of [the Department of] Education's data, the number of schools where 90 to $100 \%$ of the students were eligible for free or reduced-price lunch and 90 to $100 \%$ of the students were Black or Hispanic grew by $143 \%$ from school years $2000-01$ to $2013-$ 14."); see also Erica Frankenberg, Assessing the Status of School Desegregation Sixty Years After Brown, 2014 MiCH. ST. L. REV. 677, 678 (2014) (documenting that nearly 40\% of African American students and more than 43\% of Latino/a students attend intensely segregated schools).

${ }^{17}$ See Erwin Chemerinsky, Making Schools More Separate and Unequal: Parents Involved in Community Schools v. Seattle School District No. 1, 2014 MICH. ST. L. REV. 633 (2014) ("By every measure, public schools are becoming more racially segregated. The Supreme Court deserves a great deal of the blame for this.").

${ }^{18}$ See john a. powell, The Tensions Between Integration and School Reform, 28 HASTINGS ConST. L.Q. 655, 681 (2001) ("Desegregation has come to mean numeric balance of racial and ethnic groups within a school..]").
} 
constitutional muster by merely moving students of color into previously all-white schools. ${ }^{19}$ Questions about the quality of the education and who was bearing the larger burden of reaching these numeric goals were set aside. ${ }^{20}$ Racial balancing was apparently challenging enough for courts without addressing these additional points. ${ }^{21}$

As a result, even successfully desegregated schools achieved numeric compliance but fell well short of the original intentions of Brown. ${ }^{22}$ Schools became desegregated but were never fully integrated. The difference between these terms is instructive. Martin Luther King observed the difference more than fifty years ago, explaining "as America pursues the important task of respecting the 'letter of the law,' i.e., compliance with desegregation decisions, she must be equally concerned with the 'spirit of the law,' i.e., commitment to the democratic dream of integration." 23 As the Supreme Court acknowledged, removing the obstacles of segregation was only meant to serve as "the first step." As a legal remedy for the harms of segregation, desegregation was never going to be enough, on its own. ${ }^{25}$

Integration, on the other hand, naturally involves the removal of the structures of segregation, but it also seeks to address more than just diversity in terms of numbers. ${ }^{26}$ Actual integration requires going beyond demographics, to include reforming the classroom and curriculum, and diversifying the teaching ranks. It breaks through school district boundaries to forge metropolitan-wide solutions. It requires changes beyond education, connecting housing and

${ }^{19}$ The Supreme Court eventually decided that even that was no longer required. See Board of Education of Oklahoma City v. Dowell, 498 U.S. 237, 242 (1991) (permitting a school district to proceed with a new plan even though the new plan would guarantee that "a number of previously desegregated schools would return to primarily one-race status[.]"). In fact, as a result of the Court's approved plan, more than half of the schools in that district would be resegregated. See id. at 242 (admitting that under the new plan, 11 of 64 elementary schools would be greater than $90 \%$ African American, while 22 would be less than 10\% African American, leaving only 31 of the 64 "racially mixed.").

${ }^{20}$ See infra notes 53-63 (discussing how desegregation plans disproportionately burdened students of color).

${ }^{21}$ See generally J.W. Peltason, FifTy-Eight Lonely MEN: Southern Federal JudGes AND SCHOOL DESEGREGATION 93-134 (1961) (detailing federal courts' struggles with school desegregation).

${ }^{22}$ One presumption that drove the initial litigation was that by changing the racial mix in schools, larger changes would eventually be possible. See Robert A. Garda, Jr., Coming Full Circle: The Journey from Separate but Equal to Separate and Unequal Schools, 2 DUKE J. CONST. L. \& PUB. POL'Y 1, 45 (2007) (noting that the lawyers who brought Brown were primarily interested in the "social benefits of integration," believing that "by altering the racial composition of schools they could re-engineer society along nonracial fault lines").

${ }^{23}$ ReV. DR. MARTIN Luther KING, JR., The Ethical Demands for Integration, in A TeSTAMENT OF HoPE: THE ESSENTIAL WRITINGS OF MARTIN LuTHER KING, JR. 117, 118 (James Melvin Washington ed., 1991).

${ }^{24}$ See Green v. Cty. Sch. Bd. of New Kent Cty., 391 U.S. 430, 435-36 (1968) ("It is of course true that for the time immediately after Brown II the concern was with making an initial break in a long-established pattern of excluding Negro children from schools attended by white children. The principal focus was on obtaining for those Negro children courageous enough to break with tradition a place in the 'white' schools. Under Brown II that immediate goal was only the first step, however.") (citations omitted) (emphasis added).

${ }^{25}$ See Lia B. Epperson, True Integration: Advancing Brown's Goal of Educational Equity in the Wake of Grutter, 67 U. PITT. L. REV. 175, 202 (2005) ("Fifty years after the Court's ruling regarding segregation, however, it is painfully apparent that the elimination of the legal structure of racial segregation has not been the panacea that many hoped it would be."). The racial hierarchy still exists, according to Professor Drew Days, former Assistant Attorney General for Civil Rights, because "the same racist tendencies in America that created and maintained segregated schools did not disappear overnight once desegregation was mandated. "Rather, they merely found new opportunities in this new arrangement to disadvantage the black community." Drew S. Days, III, Brown Blues: Rethinking the Integrative Ideal, 34 WM. \& MARY L. REV. 53, 56 (1992).

${ }^{26}$ See powell, supra note 18 , at 681 ("[I]ntegration is not simply a goal in terms of the schools in which students learn as a static site, but requires a transformation of the setting in which the identities of students are formed and form others."). 
education policy. And because of the most recent Supreme Court decision, it requires using other metrics, in addition to race, to promote broad diversity in the public schools.

School segregation remains a major problem today because previous desegregation efforts were either incomplete, ineffective, or both. Even the most robust efforts at addressing school segregation limited their focus to balancing the number of students of color with the number of white students. These efforts too often ignored other important factors in the classroom, such as inclusive curriculum and diverse teaching ranks. Previous desegregation also disregarded the connection between education and housing policy. If America is to finally integrate its schools, these previously ignored and disregarded factors must become central features in strategies to address school segregation.

Part I of this article provides a brief overview of both the positive impact and the negative history of desegregation in America's schools. Part II examines some current examples of desegregation plans and discusses not only the benefits of each, but also how each program suffers from critical flaws and drawbacks. Part III of this article uses this understanding of the limitations to current desegregation to suggest additional approaches that could help make the leap from desegregation to actual integration in a manner more consistent with the original "promise" of Brown. ${ }^{27}$

\section{I: THE LEGACY OF DESEGREGATION: SUCCESSES AND LIMITS}

\section{A. Desegregation's Main Achievements}

Decades of research supports the positive impact of school desegregation. Study after study has shown that all students - both students of color and white students - reap tremendous benefits from diverse classrooms and schools. ${ }^{28}$ Perhaps no better demonstration of the consensus on the benefits of desegregation was in the amicus briefs leading up to the Parents Involved decision. ${ }^{29}$ Of the hundreds of scholars and researchers from across many different disciplines who submitted amicus briefs on the subject, only a handful took the position that desegregation was not beneficial. ${ }^{30}$

\footnotetext{
${ }^{27}$ In Parents Involved, Justice Breyer described the "promise of Brown" while justifying the Brown decision as "this Court's finest hour." 551 U.S. at 867-68 (Breyer, J., dissenting) ("It was the promise of true racial equality --not as a matter of fine words on paper, but as a matter of everyday life in the Nation's cities and schools.").

${ }^{28}$ The Supreme Court agreed. See, e.g., Grutter v. Bollinger, 539 U.S. 306, 343 (2003) (upholding an admissions plan "to further a compelling interest in obtaining the educational benefits that flow from a diverse student body[.]"). Importantly, the Court also recognized the value of diversity beyond the educational benefits for individual students. See id. at 332 ("Effective participation by members of all racial and ethnic groups in the civic life of our Nation is essential if the dream of one Nation, indivisible, is to be realized."). The United States Departments of Justice and Education reached the same conclusion. See U.S. DeP'T Of Justice \& U.S. DeP'T Of EduC., GuidanCE ON THE VOLUNTARY USE OF RACE TO ACHIEVE DIVERSITY AND AVOID RACIAL ISOLATION IN ELEMENTARY AND SECONDARY SCHOOLS [hereinafter DEP'TS OF JUSTICE \& OF EDUC. GuIDANCE] 1 (2011), available at http:// www2.ed.gov/about/offices/list/ocr/docs/guidance-ese-201111.html ("Providing students with diverse, inclusive educational opportunities from an early age is crucial to achieving the nation's educational and civic goals.").

${ }^{29}$ See generally, R.L. LINN \& K.G. WELnER, NAT'L ACAD. OF EDUC., COMM. ON SOC. SCI. RES. EvidENCE ON RACIAL DIVERSITY IN SCHOOLS 45 (R.L. Linn \& K.G. Welner eds., 2007) (cataloging all briefs submitted by both sides and concluding that "the research evidence supports the conclusion that the overall academic and social effects of increased racial diversity are likely to be positive").

${ }^{30}$ As Professor Myron Orfield explains, the Court was presented with briefs that included "a consensus statement on behalf of thousands of tenured professors and credentialed researchers in the two academic fields best situated to evaluate integration's effects" along with a brief on behalf of 553 scholars, all supporting the position that desegregation has benefitted students of color. "Disputing the benefits of desegregation were six purported experts, only two of whom had published significant peer-reviewed studies on the topic." Myron Orfield, Milliken, Meredith,
} 
While far from perfect, ${ }^{31}$ desegregation plans at the very least prohibited the most egregious examples of segregated schools and improved educational opportunities for many African American students. ${ }^{32}$ Court-ordered desegregation transformed the school systems in the South, in particular, into the least segregated in the country. ${ }^{33}$ Mandated desegregation plans impacted most of the school districts where African American students attended school. ${ }^{34}$ Indeed, it created a sufficient number of desegregated schools for long enough to provide desegregation's proof of concept. ${ }^{35}$

Desegregation may be the only education policy that has improved the academic and social outcomes for students of color at a system-wide level in American public schools. ${ }^{36}$ Other reforms have shown limited promise and have generally failed to provide more equitable outcomes for students of color. ${ }^{37}$ Many of these reform efforts occur only at a school-by-school level. For example, some charter school initiatives have shown promise on a small scale, but they have generally failed to deliver improvements consistently and never across entire districts. ${ }^{38}$

and Metropolitan Segregation, 62 UCLA L. REV. 364, 424 (2015); see also Roslyn Arlin Mickelson, The School Desegregation Cases and the Uncertain Future of Racial Equality: Twenty-First Century Social Science on School Racial Diversity and Educational Outcomes, 69 OHIO ST. L.J. 1173, 1191-92 (2008) (criticizing the main opposing social science amicus briefs and finding that their "usefulness for understanding contemporary debates about the effects of educational diversity on outcomes is questionable given the dated nature of the empirical studies ... and their many methodological weaknesses").

${ }^{31}$ For a discussion of the drawbacks of how desegregation plans have been designed and implemented, see infra notes 48-65 and accompanying text (collecting cases and studies).

${ }^{32}$ As a result of desegregation, "[b]y almost every measurable standard, African Americans as a group were significantly better off in 2004 than they had been in 1954." KLUGER, supra note 9, at 780. Desegregation litigation had enormous ripple effects, too. See Hampton v. Jefferson Cnty. Bd. of Educ., 102 F. Supp. 2d 358, 379 (W.D. Ky. 2000) (noting that the Brown "and its progeny established a moral imperative to eradicate racial injustice in the public schools"). Education was only the first domino to fall. See, e.g., Martin v. Charlotte-Mecklenburg Board of Education, 475 F. Supp. 1318, 1324 (W.D.N.C. 1979), aff'd, 626 F.2d 1165 (4th Cir. 1980), cert. denied, 450 U.S. 1041 (1981) (explaining that previous to the Brown decision, racial segregation laws impacted "almost all public (and many private) facilities, accommodations, and activities, including, among others, schools, colleges, orphanages, medical facilities, prisons and other detention facilities, theaters, busses, trains, restaurants, restrooms, water fountains, tax records, housing, financing of housing, zoning, weddings, and burials").

${ }^{33}$ See Garda, supra note 22, at 41 ("In thirty short years, Brown changed the centuries-old structure of de jure segregation and transformed schools in the South from the most segregated to the least segregated in the country.").

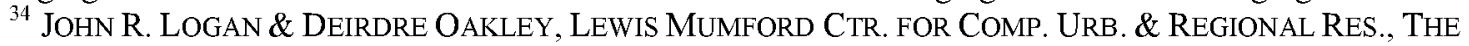
CONTINUING LEGACY OF THE BROWN DECISION: COURT ACTION AND SCHOOL SEGREGATION 2 (2004), available at https://s4.ad.brown.edu/Projects/usschools/reports/report2.pdf. As of 2000, 75\% of African American students in the South and $62 \%$ of African American students in the rest of the country were attending schools in districts that were under mandatory desegregation decrees at some time between 1950 and 1964. Id.

${ }^{35}$ Conversely, the long history of segregated schools has clearly demonstrated the great harm from segregation. See G. ORFIELD \& FRANKENBERG, supra note 7, at 37 ("The consensus of nearly 60 years of social science research on the harms of school segregation is clear: separate remains extremely unequal. Racially and socioeconomically isolated schools are strongly related to an array of factors that limit educational opportunities and outcomes.").

${ }^{36}$ Desegregation orders are typically system-wide, since segregation tends to impact the entire school district. See e.g., Taylor v. Ouachita Par. Sch. Bd., 965 F. Supp. 2d 758, 769 (W.D. La. 2013) (recognizing the "continuing duty [for school officials] to eliminate the system-wide effects of earlier discrimination" due to segregation); see also, Swann v. Charlotte-Mecklenburg Bd. of Educ., 402 U.S. 1, 15 (1971) ("Once a right and a violation have been shown, the scope of a district court's equitable powers to remedy past wrongs is broad, for breadth and flexibility are inherent in equitable remedies.").

${ }^{37}$ Holley-Walker, supra note 15, at 458 ("Despite all of the education reform efforts of the last several decades, there is a persistent racial achievement gap.").

${ }^{38}$ Derek W. Black, Civil Rights, Charter Schools, and Lessons to Be Learned, 64 FLA. L. REV. 1723, 1770 (2012) (despite some charter schools performing well "on the whole, charter schools struggle to perform at levels 
Other district-wide policies, such as funding increases, have similarly fallen short of reliably improving outcomes for students of color. ${ }^{39}$

Importantly, desegregation has demonstrated positive benefits both in terms of academic achievement and social factors. ${ }^{40}$ Desegregation has dependably shown significant gains along a wide range of life outcomes, including impacts on housing, employment, and health. ${ }^{41}$ Its greatest impact on students is perhaps the effect on racial attitudes and the diminishing of interracial prejudice, ${ }^{42}$ which extends to both students of color and white students. ${ }^{43}$

Desegregation has shown particularly significant positive impacts on academic achievement. After decades of implementation, studies consistently conclude that desegregation led to important gains in various academic measures for students of color. ${ }^{44}$ Test scores for students of color improved significantly in desegregated settings. ${ }^{45}$ Unlike other major reforms

comparable to public schools and frequently underperform significantly"); Steven L. Nelson, Still Serving Two Masters? Evaluating the Conflict between School Choice and Desegregation under the Lens of Critical Race Theory, 26 B.U. PUB. INT. L.J. 43, 47 (2017) ("Academic achievement data does not link substantial academic gains to student enrollment in charter schools..."). Charter schools also contribute to segregation. See id. at 47 ("[I]t is generally accepted in peer-reviewed research that charter schools aid in the resegregation of public school students."); Joseph P. Viteritti, The Federal Role in School Reform: Obama's "Race to the Top', 87 Notre Dame L. REV. 2087, 2114 (2012) (citing evidence that "charter schools are more racially isolated than regular public schools"); Adlai TeFERa, et al., C.R. Project, InTEgrating Suburban SchoOls: How to BenEFit From GROWING DIVERSITY AND AVOID SEGREGATION 18 (2011) ("Studies have long documented patterns of severe segregation in charter schools[.]"). The NAACP even issued a resolution calling for a moratorium on charter school expansion, in part, because "in some cases, charter schools have become a school model that is used to segregate students." RESOLUTION OF THE NAACP DELEGATES, July 2010 (approved Oct. 15, 2010) (on file with author).

${ }^{39}$ See Molly S. McUsic, The Future of Brown v. Board of Education: Economic Integration of the Public Schools, 117 HARV. L. REV. 1334, 1353 (2004) (finding that "[i]n school district after school district, large funding increases have proved inadequate to overcome the educational disadvantages faced by poor, underachieving students"). Segregated schools do not provide better educational performance if they receive more money. Id.

${ }^{40}$ See, e.g., Danielle Holley-Walker, After Unitary Status: Examining Voluntary Integration Strategies for Southern School Districts, 88 N.C. L. REV. 877, 880 (2010) ("An impressive array of literature documents that [students of color] reap educational, social, and economic benefits from racially integrated schools.").

${ }^{41}$ See Amy Stuart Wells, The "Consequences" of School Desegregation: The Mismatch Between the Research and the Rationale, 28 HASTINGS CONST. L.Q. 771, 795 (2001) ("[T]he literature demonstrates that black graduates of desegregated schools are more likely to be working in white collar and professional jobs in integrated corporations and institutions. These graduates are also more likely to have integrated social and professional networks through which they learn about personal and professional opportunities."); Joseph O. Oluwole \& Preston C. Green III, Harrowing through Narrow Tailoring: Voluntary Race-Conscious Student Assignment Plans, Parents Involved and Fisher, 14 WYO. L. REV. 705, 705-06 (2014) ("Other benefits of a racially diverse education include less residential segregation, higher income for minorities, greater civic engagement, increased parental involvement, and better student preparation for a diverse workforce.").

${ }^{42}$ See, e.g., Pettigrew \& Tropp, supra note 12, at 766 (concluding from a meta-analysis of 515 studies that interracial prejudice diminishes with intergroup racial contact); see also Richard D. Kahlenberg, Socioeconomic School Integration, 85 N.C. L. REV. 1545, 1555 (2007) (arguing that racial integration is important for furthering the goals of fostering tolerance and good citizenship).

${ }^{43}$ Robert A. Garda, The White Interest in School Integration, 63 FLA. L. REV. 599, 622 (2011) ("[T] here is virtually unanimous agreement that diverse educational environments better prepare white students for a multiracial work environment.").

${ }^{44}$ Maureen T. Hallinan, Diversity Effects on Student Outcomes: Social Science Evidence, 59 OHIO ST. L.J. 733, 741$42,744-45$ (1998) (summarizing from multiple studies that demonstrate the academic benefits to students of color from desegregated learning environments).

${ }^{45}$ See, e.g., Mickelson \& Bottia, supra note 11, at 1028 ("The quantity and quality of the studies that discuss the effects of racial composition collectively offer strong evidence that racially isolated minority schools hinder mathematics outcomes and diverse schools foster higher performance. Several studies report that racially diverse 
of the past decades, desegregation has demonstrated a significant impact on the "achievement gap." ${ }^{46}$ School desegregation also has lasting impacts on life outcomes beyond graduation. ${ }^{47}$

\section{B. Desegregation Setbacks and Design Flaws}

Despite significant gains in both social and academic realms, desegregation plans have historically fallen considerably short of Brown's original purpose. ${ }^{48}$ In perhaps prophetic words, Supreme Court Justice Thurgood Marshall, lead counsel on the Brown case, noted that "[d] esegregation is not and was never expected to be an easy task." ${ }^{49}$ Resistance in the white community to desegregation court orders created enormous barriers to making schools more diverse. Desegregation plans often catered to white interests, bowing to political and social pressures from the "Massive Resistance" that emerged after the Brown decision. ${ }^{50}$

Facing such resistance, desegregation plans failed in two important respects. One major limitation to desegregation plans stemmed from their exclusive focus on balancing the demographics of students. Failing to include more "holistic remedial measures," desegregation plans acted to maintain, rather than eliminate, the inequality that Brown sought to address. ${ }^{51}$

schools offer more students the chance to excel in math than either racially isolated White schools or isolated minority schools.").

${ }^{46}$ See M. Orfield, supra note 30, at 425 ("Since the research also shows that integrated schools do not lower test scores for white students, racially integrated schools are one of the very few strategies demonstrated to ease one of the most difficult public policy problems of our time -- the racial achievement gap.").

${ }^{47}$ See john a. powell, Living and Learning: Linking Housing and Education, 80 MINN. L. REV. 749, 789-90 (1996) ("The beneficial effects of social integration run deep and continue to influence the lives of students in integrated schools long after their formal education."); G. ORFIELD \& FRANKENBERG, supra note 7, at 40 ("Perhaps most important of all, evidence indicates that school desegregation can have perpetuating effects across generations."); see also Rucker C. Johnson, Long-Run Impacts of School Desegregation and School Quality 2 (Nat'l Bureau of Econ. Research, Working Paper No. 16664, 2011) (on file with author) (explaining that school desegregation increased education, occupational attainments, and several other benefits including the specific findings that students who attended desegregated schools for at least five years earned $25 \%$ more than their counterparts from segregated setting and were also in far better health by middle-age, too).

${ }^{48}$ See Jim Hilbert, Restoring the Promise of Brown: Using State Constitutional Law to Challenge School Segregation, 46 J. OF L. \& ED. 1, 5 (2017) ("The architects of the Brown case sought not just to end systems of segregation, but to promote full integration and inclusion of African Americans into mainstream life.").

${ }^{49}$ Milliken v. Bradley, 418 U.S. 717,814 (1974) (Marshall, J., dissenting).

${ }^{50}$ See Sumi Cho, From Massive Resistance, to Passive Resistance, to Righteous Resistance: Understanding the Culture Wars from Brown to Grutter, 7 U. PA. J. CONST. L. 809, 815 (2005) (detailing the many ways in which white politicians and community members executed a policy of "Massive Resistance" to thwart desegregation); see also Charles T. Clotfelter, After Brown: THe Rise AND Retreat of SCHOOl DeSEGREGation 8 (2004) (" $[T]$ he execution of the policy of desegregation was frustrated, and ultimately blunted, by four factors: apparent white aversion to interracial contact, the multiplicity of means by which whites could sidestep the effects of the policy, the willingness of state and local governments to accommodate white resistance, and the faltering resolve of the prime movers of the policy."). Massive Resistance has been followed up with just plain reluctance on the part of many whites to participate in desegregation. Michelle Adams, Radical Integration, 94 CAL. L. ReV. 261, 265 (2006) ("While neither universal nor uniform, white aversion to interracial contact has been a fixture of the social and political landscape throughout the desegregation era.").

${ }^{51}$ See Epperson, supra note 25, at 208 ("These remedies, purported to rectify the violation of constitutional rights identified in Brown, were grounded in an idealistic assumption that a focus on racial balancing in schools was sufficient without a corresponding frontal attack on the deep-rooted notions of racial hierarchy inherent in our society."). By maintaining an exclusive focus on demographics, "the courts allowed racial prejudices that affected the hearts and minds of both black and white students to persist." 
Mere number balancing "helped to reinforce, rather than eradicate," the many harms that resulted from perpetual systems of inequality. ${ }^{52}$

Another major limitation was that desegregation plans too frequently imposed harsh burdens on African American students and communities. ${ }^{53}$ The most common impact was seen in disproportionate transportation of African American students to white schools. ${ }^{54}$ Despite the Supreme Court's explicit concern about this practice, ${ }^{55}$ desegregation plans too often reshuffled the demographic patterns of schools by relying solely on the transfer of African American students. ${ }^{56}$

In doing so, such plans offensively imposed costs "squarely on the victims of past state sponsored segregation." ${ }^{, 57}$ Even worse, most desegregation plans often reflected only a small percentage of African American students in otherwise completely white institutions. ${ }^{58}$ In these particular circumstances, the philosophy of desegregation rested on the "assimilation" of African American students into a white culture. ${ }^{59}$ Such one-sided efforts at desegregation regularly resulted in isolation of African American students and insensitivity to their experiences. ${ }^{60}$ Schools under desegregation orders often ignored issues of race and failed to "foster cross-racial understanding and appreciation of African American heritage," among other major flaws. ${ }^{61}$

By focusing almost entirely on the shuffling of African American students to address demographic disparities, these desegregation plans impacted the broader African American community as well. Such plans often included the closing of schools in African American

${ }^{52} I d$. at 207.

${ }^{53}$ See Days, supra note 25 , at 55 (concluding that "the black community has paid, in some instances, a high price for desegregation").

${ }^{54}$ See Epperson, supra note 25, at 207 (documenting how school districts placed the burden on African American children through disproportionate transportation burdens); see also Days, supra note 25, at 55 (explaining that "the burden of busing has fallen disproportionately upon black children").

${ }^{55}$ As the Court noted, "[R]ather than further the dismantling of the dual system, the plan has operated simply to burden children and their parents with a responsibility which Brown II placed squarely on the School Board." Green, 391 U.S. at 442-43.

${ }^{56}$ powell, supra note 47 , at 775 (observing that "black children have been bused to white schools, while white children are often not bused to black schools").

${ }^{57}$ Nelson, supra note 38 , at 51.

${ }^{58}$ See Adams, supra note 50, at 264 (describing the pattern of "continuing white resistance [which has resulted] to no] more than a 'token black presence' in white communities").

${ }^{59}$ See powell, supra note 47, at 775 ("School integration policies have accepted the assimilation model, too often focusing on 'fixing' or assimilating black children into white culture.").

${ }^{60}$ Wells, supra note 41, at 787 ("African American transfer students had to endure the racial and cultural insensitivity of whites in the suburbs in order to succeed there. Many of the white teachers, administrators, and students of suburbia regularly made the transfer students feel unwanted and unwelcome. These educators often failed to consider the perspective of black students who traveled many miles each day in search of a better education."); see also Doris Y. Wilkinson, Integration Dilemmas in a Racist Culture, 33 SOCIETY 27, 31 (1996) ("With only a handful of black students in each classroom, they experience prolonged isolation in predominantly white settings, where they are often 'exposed to denigrating racial imagery from the teachers, tracking, low expectations, or race hatred."').

${ }^{61}$ See Brandon Paradise, Racially Transcendent Diversity, 50 U. LouISvILLE L. REV. 415, 448 (2012) ("Specifically, during the height of desegregation, it was not uncommon for schools undergoing desegregation to conduct business as usual and to ignore the issue of race. ... In practice, this meant that there was often very little, if any, effort to foster cross-racial understanding and appreciation of African-American heritage and history."); see also AMY Stuart Wells Et Al., Both Sides Now: The Story OF School Desegregation’s Graduates 141 (2009) ("The lack of a dialogue about race combined with the maintenance of a traditional Eurocentric curriculum became a de facto assimilationist project in these schools."). 
neighborhoods, which had the double impact of removing a school plus closing a community center, as schools often served both functions in African American communities. ${ }^{62}$ African American teachers and administrators were disproportionately fired or demoted. ${ }^{63}$

In addition, desegregation plans focused on the demographics only at the level of the school building, allowing schools to re-segregate students once inside the schoolhouse doors by "tracking" students into separate classrooms. Even schools that are "technically" desegregated, because of their demographic make-up across the entire school building, could segregate students inside the building. ${ }^{64}$ Schools often reacted to orders to desegregate "by putting in place tracking systems as a means to place African American and white students in different classrooms." 65

\section{Withdrawal of Support for Desegregation}

Concerns about desegregation were expressed early on by many civil rights activists, particularly in the African American community. ${ }^{66}$ After a mixed record of imposing disproportionate burdens on African Americans, many have more than questioned its viability to fulfil its initial promise. ${ }^{67}$ After six decades, there is a perception that "[i]ntegration no longer captivates the progressive imagination; it no longer moves those concerned with eliminating racial inequality." 68 Part of the issue is that there are few examples of truly successful desegregation plans to reference. ${ }^{69}$

${ }^{62}$ Days, supra note 25 , at 55 .

${ }^{63} \mathrm{Id}$. This often had the "deleterious effect of decimating a cadre of powerful academic role models for black and white students." Epperson, supra note 25, at 207; see also infra notes 247-249 and accompanying text (explaining the history of firing teachers and administrators in the wake of the Brown decision).

${ }^{64}$ See Jacquelyn L. Bridgeman, On Shifting Hearts and Minds: Interraciality, Equal Value, and Equality, 16 J. GENDER RACE \& JUST. 705, 717 n.86 (2013) (explaining how "tracking” often resulted in separating students by race into different classrooms and ensuring that "norms of white privilege and whites as the standard remain intact"); Patricia A. Broussard, Brown Did Not Fail America, America Failed Brown, 47 How. L.J. 829, 840-41 (2004) (discussing the issue of segregating forces inside schools, such as tracking).

${ }^{65}$ Angelia Dickens, Revisiting Brown v. Board of Education: How Tracking Has Resegregated America's Public Schools, 29 Colum. L.J. \& Soc. ProBS. 469, 473 (1996); see also Amy Stuart Wells et al., The Space Between School Desegregation Court Orders and Outcomes: The Struggle to Challenge White Privilege, $90 \mathrm{VA} . \mathrm{L}$. REV. 1721,1735 (2004) ('From blatant tracking practices that labeled students as 'gifted' or 'non-gifted' as early as kindergarten and then channeled them through the grade levels in the 'appropriate' classes, to more subtle forms of sorting students that used teacher recommendations to decide who got into the best classes, the schools and districts we studied managed to create incredible and consistent levels of segregation within each school.").

${ }^{66}$ See, e.g., Malcolm X \& James Farmer, Separation or Integration: A Debate, Dialogue, May 1962, reprinted in Black Protest Thought in the Twentieth Century 387, 393 (August Meier et al. eds., 1971) (Malcolm X expressing concerns that "we don't have any hope or confidence or faith in the American white man's ability to bring about a change in the injustices that exist, instead of asking or seeking to integrate into the American society we want to face the facts of the problem the way they are, and separate ourselves"); see also Harry T. Edwards, The Journey From Brown v. Board of Education to Grutter v. Bollinger: From Racial Assimilation to Diversity, 102 MiCH. L. REV. 944, 949 (2004) (noting that the "meaning and desirability of integration has long been the subject of disagreement among African Americans"); KwAme Ture \& Charles V. HAMILTON, BlaCk POWER: ThE POLITICS OF LIBERATION IN AMERICA 54 (1992) (calling desegregation a "subterfuge for the maintenance of white supremacy" because it reinforced the idea that "white' is automatically superior and 'black' is by definition inferior").

${ }^{67}$ See Adams, supra note 50, at 264 ("Indeed, there is an increasing belief that integration is no longer a viable social policy, but rather a failed social experiment.") (internal citation omitted).

${ }^{68}$ See $i d$. at 265 ("[I]ntegration is hardly a leading philosophy among progressives or in the legal academy.").

${ }^{69}$ See powell, supra note 47, at 753 ("Why have we seemingly given up on integration? In all likelihood, these policy surrenders are partially a response to the hopelessness and frustration experienced when we realize the 
School districts, as well, have seemingly given up on desegregation as a policy for improving student outcomes. As upsetting as the Supreme Court's last ruling on the subject was for Justice Stephen Breyer, ${ }^{70}$ the Court's decision may not be the main reason that so many districts have moved away from desegregation. As Professors Erica Frankenberg and Chinh Q. Le point out, "the law alone cannot account for the scores of school districts and communities that have essentially offered no strategy for or even intention of addressing racial, ethnic, and socioeconomic isolation in their schools, despite the growing segregation they are and have been witnessing." 71 As Professor James Ryan wrote ten years ago, the reality is that "racial integration is not on the agenda of most school districts and has not been for over twenty years." 72

\section{II: SOME PROMISING EXAMPLES OF DESEGREGATION PlANS}

Initial efforts to desegregate schools after the Brown decision were virtually nonexistent. ${ }^{73}$ In the first decade after Brown, almost nothing had changed with respect to school segregation. School districts in the South, in particular, were basically unchanged despite the Supreme Court's decision. ${ }^{74}$ The passage of the Civil Rights Act in 1964 and a string of proactive Supreme Court decisions, however, pushed desegregation policy into its most active phase toward the end of the $1960 \mathrm{~s}^{75}$ For the first time, the Court not only articulated specific guidelines for what districts must do to desegregate their schools, ${ }^{76}$ but also sanctioned its most radical remedy - mandatory busing. ${ }^{77}$

persistence of segregation. Integration can be a tough concept to embrace when one considers that it cannot claim many examples.").

70 Justice Breyer's dissent called Parents Involved "a decision that the Court and the Nation will come to regret." Parents Involved in Community Schools v. Seattle School Dist. No. 1, 551 U.S.701, 868 (2007) (Breyer, J., dissenting). So strongly did Justice Breyer feel about his opposition to the Court's ruling that he read aloud his 77 page dissent from the bench. Linda Greenhouse, Justices Limit the Use of Race in School Plans for Integration, N.Y. TIMES, June 29, 2007, pAl available at http://www.nytimes.com/2007/06/29/washington/29scotus.html?_r=0.

${ }^{71}$ Erica Frankenberg \& Chinh Q. Le, The Post-Parents Involved Challenge: Confronting Extralegal Obstacles to Integration, 69 OHIO ST. L.J 1015, 1021 (2008). The Court decision just "reinforces and provides an excuse for what school boards don't want to do anyway." See also Chemerinsky, supra note 17, at 638 .

${ }^{72}$ James E. Ryan, The Supreme Court and Voluntary Integration, 121 HARV. L. REV. 131, 132 (2007); see also Danielle Holley-Walker, Educating at the Crossroads: Parents Involved, No Child Left Behind and School Choice, 69 OHIO ST. L.J. 911,935 (2008) (deducing that, given the pressures and emphasis placed on student performance by No Child Left Behind, school integration may not be a top priority for the majority of schools).

${ }^{73}$ Of course, government officials and some white community members in the South, however, were extremely active in resisting potential desegregation, doing everything from setting up private all-white schools, depriving policemen of their retirement and disability if they failed to enforce the state's segregation laws, and making it illegal for NAACP members to hold government jobs. See GERALD N. ROSENBERG, THE HoLLOw HoPE: CAN COURTS BRING ABOUT SoCIAL CHANGE? 79 (1991) (reporting that "creativity in finding ways to avoid [Brown] [that] was seemingly inexhaustible"); see also supra note 50 and accompanying text (discussing "Massive Resistance" to Brown in the white community).

${ }^{74}$ See Katy J. Harriger, The Civil Rights Act of 1964 and School Desegregation: A Double-Edged Sword?, 6 WAKE FOREST J.L. \& POL'Y 157, 172 (2016) ("Compliance with Brown in the first decade after the decision was dismal."); G. ORFIELD \& FRANKENBERG, supra note 7, at 4 ("Virtually no whites were in historically black schools, nor were black teachers and administrators in white schools. For all practical purposes, it was segregation as usual or 'segregation forever,' as some of the South's politicians promised. In the great majority of the several thousand southern districts nothing had been done.").

${ }^{75} \mathrm{G}$. Orfield, supra note 10, at 101-02; see also Harriger, supra note 74, at 183 (discussing how for the first time the Court required districts "to take affirmative actions to integrate the schools.").

${ }^{76}$ See Green, 391 U.S. at 441-42 (requiring school districts to show evidence of integration and equity in the areas of student and faculty assignment, staff, facilities, extracurricular activities, and transportation). The Court held that school boards in segregated districts were "clearly charged with the affirmative duty to take whatever steps might be 
The efforts of both the Court and the federal government during this time led to significant changes in public schools. ${ }^{78}$ By $1972,36 \%$ of African American students in the South attended schools that were majority white, and this number reached $44 \%$ in $1988{ }^{79}$ This momentum would not last, however, as a "seismic shift" in the Court began unravelling the scope of desegregation remedies by the mid-70s. ${ }^{80}$ In Milliken $v$. Bradley, the Court began its long retreat ${ }^{81}$ from potentially effective desegregation by essentially prohibiting interdistrict, metropolitan-wide remedies. ${ }^{82}$

As the Court backed away from desegregation, prominent elected officials forcefully opposed mandatory busing plans. Perhaps the most visible opponent at the time was President Richard Nixon. In a 1972 nationally televised address dedicated to "one of the most difficult issues of our time - the issue of busing," President Nixon clarified his "well known" position against busing and announced the introduction of legislation to "call an immediate halt to all new busing orders by federal courts." 83 Other politicians followed suit and used terms like "forced busing" to raise the fears of white parents worried about increasing numbers of students of color in previously all-white schools. ${ }^{84}$

necessary to convert to a unitary system in which racial discrimination would be eliminated root and branch." $I d$. at 437-38.

${ }^{77}$ The Supreme Court first sanctioned mandatory busing of children as an acceptable means of achieving desegregation in 1971. See Swann, 402 U.S. at 29-30 (upholding the district court's order that included busing to promote desegregation while noting that "[d]esegregation plans cannot be limited to the walk-in school"); see also David J. Garrow, The Federal Courts and School Desegregation in the 1970's, 21 LAW \& SoC'Y REV. 879, 879 (1988) ("Swann is most widely known as the first Supreme Court ruling to sanction busing of students for the purpose of racial desegregation[.]"). The term "busing," which has become synonymous with mandatory desegregation, is ironic given how most students already rode a bus to school, with or without a desegregation order. See Swann 402 U.S. at 30 ("Bus transportation has been an integral part of the public education system for years, and was perhaps the single most important factor in the transition from the one-room schoolhouse to the consolidated school. Eighteen million of the Nation's public school children, approximately $39 \%$ were transported to their schools by bus in 1969-1970 in all parts of the country.").

${ }^{78}$ The Swann decision in particular sparked a new energy in desegregation. See Charles L. Zelden, From Rights to Resources: The Southern Federal District Courts and the Transformation on Civil Rights in Education, 1968-1974, 32 AKRON L. REV. 471, 523 (1999) ("The impact of the Supreme Court's decision in Swann was electric. It gave constitutional force to the adoption by District Courts of race-based standards for integration, school pairing and mandatory busing on a wide scale.").

${ }^{79}$ KeVin Brown, RaCe, LAw ANd Education in the Post-Desegregation Era: Four Perspectives on DESEGREGATION AND RESEGREGATION 177 (2005). By contrast, less than 1\% of African American students in the South attended schools that were majority white in 1964. G. Orfield, supra note 10, at 101.

${ }^{80}$ See Erica Frankenberg \& Genevieve Siegel-Hawley, Choosing Diversity: School Choice and Racial Integration in the Age of Obama, 6 STAN. J. CIV. RTS. \& CIV. LIB. 219, 222 (2010) (detailing the "seismic shift in the composition of the Court" that took place over the short span of three years); see also Brad Snyder, How the Conservatives Canonized Brown v. Board of Education, 52 RuTGERS L. REv. 383, 432 (2000) (discussing the dramatic impact on Brown's interpretation from President Nixon's four Court appointees).

${ }^{81}$ In the words of Justice Thurgood Marshall, "After 20 years of small, often difficult steps toward that great end, the Court today takes a giant step backwards." Milliken, 418 U.S. at 782 (Marshall, J., dissenting);

${ }^{82}$ See infra notes 162-64 and accompanying text (describing the impact of the Milliken decision in more detail). ${ }^{83}$ Address to the Nation on Equal Employment Opportunities and School Busing, PUB. PAPERS OF PRESIDENT RICHARD NIXON 425-29 (1972) available at http:/www.presidency.ucsb.edu/ws/?pid=3775. Nixon also said that he was willing to consider a constitutional amendment to stop busing, but that would take too long. See id. ("What we need is action now--not action 2, 3, or 4 years from now. And there is only one effective way to deal with the problem now. That is for the Congress to act.").

${ }^{84}$ See Frankenberg \& Siegel-Hawley, supra note 80, at 225 ("The suddenly fast-moving integrative transformation of southern schools became fodder for politicians who coined the label 'forced busing' to describe--and stoke-opposition to desegregation.") (internal citations omitted). 


\section{A. Choice-Based Options}

\section{Magnet Schools}

In the wake of the changes in the Court and the political attacks on mandatory busing, school districts began moving toward "choice-based options" to further desegregation policies. Such plans were often at the initiation of the school districts themselves "rather than outside enforcement agencies." ${ }^{85}$ Given the mood of the public, school districts were interested in finding more palatable means to address segregation. ${ }^{86}$ "Magnet schools subsequently rose to prominence as a widely accepted strategy combining parental choice with desegregation." ${ }^{87}$

Relying on principles of school choice, districts created and marketed magnet schools to draw students of different racial backgrounds to new, more attractive schools. ${ }^{88}$ These magnet schools typically had an academic or curricular focus, such as science, math, or art "to attract students from across a city or even across school district lines. ${ }^{" 89}$ Early versions of magnets also included putting special programs in downtown schools to draw suburban students. ${ }^{90}$ Magnet schools became a relatively popular tool for desegregation. ${ }^{91}$ Courts even embraced the use of magnet schools to support desegregation mandates. ${ }^{92}$

The use of magnets schools has cooled off considerably in the past decade, and a number

${ }^{85}$ ClOtFel TER, supra note 50 , at 32.

${ }^{86}$ As pressure mounted against mandatory plans, districts, courts, and others were motivated to find more compromising methods. See Frankenberg \& Siegel-Hawley, supra note 80, at 225 ("As the political and judicial climate changed during the Nixon administration, many integration advocates conceded that compromises were in order.") (internal citations omitted).

${ }^{87}$ Frankenberg \& Siegel-Hawley, supra note 80, at 225; see also Frankenberg \& Le, supra note 71, at $1045-46$ ("As reliance on other desegregation strategies has gradually diminished, magnet schools have emerged as the principal means upon which school systems--particularly larger, urban school systems--now rely to advance Brown's vision of equal, integrated public education."). Despite recent drop-offs in popularity, magnet schools remain the "largest set of choice-based schools in the nation." TEFERA ET AL., supra note 38, at 3.

${ }^{88}$ Kevin Brown, The Supreme Court's Role in the Growing School Choice Movement, 67 OHIO ST. L.J. $37,57-58$ (2006) ("In order to promote integration, racial and ethnic classifications are normally used to determine the appropriate mix of the student body."); see also Craig Heeren, "Together at the Table of Brotherhood": Voluntary Student Assignment Plans and the Supreme Court, 24 HARV. BLACKLETTER L.J. 133, 183 (2008) (defining magnet schools as those schools that "offer a specialized school curriculum organized around a particular subject matter or theme, or that use a distinctive teaching methodology, and seek to attract both white and minority students from all parts of the city, and away from their neighborhood schools or private schools") (citing Mark G. Yudof et al., Educational Policy and the Law 414 (West 2002)).

${ }^{89}$ Holley-Walker, supra note 15, at 447; see also Frankenberg \& Siegel-Hawley, supra note 80, at 224 n.26 ("Magnet schools can be defined as public schools that emphasize a special curricular or theme focus, traditionally in order to attract white students to schools in minority neighborhoods.").

${ }^{90}$ ClOTFEL TER, supra note 50, at 32 (noting that this arrangement had the dual purpose of increasing desegregation and saving otherwise undesirable school buildings).

${ }^{91}$ By 2001, there were 1,736 magnet schools in the country that enrolled approximately $3 \%$ of all American students. Brown, supra note 88, at 58. Indeed, "[m]agnet schools played a key role in desegregation." HolleyWalker, supra note 15, at 447. "For many years desegregation resources focused on the funding of magnet school programs." Id. Even now, the federal government's Magnet Schools Assistance Program states that "Magnet schools are a significant part of the Nation's effort to achieve voluntary desegregation in our Nation's schools." 20 U.S.C. $\$ 7231(\mathrm{a})(1)(2017)$.

${ }^{92}$ See Frankenberg \& Siegel-Hawley, supra note 80, at 225 (describing three different federal court decisions where the district courts approved plans relying largely on magnet schools and voluntary majority-to-minority transfers, rather than mandatory transportation, to achieve desegregation). 
of new challenges have emerged. The decrease in the use of magnet schools is largely due to a reduction in interest on the part of school districts to further pursue desegregation. ${ }^{93}$ Funding, too, has been reduced, limiting the attractiveness and number of magnet schools. ${ }^{94}$ More concerning, however, is that the effectiveness of magnets to further the goals of desegregation has come into question. ${ }^{95}$ Magnet schools sometimes result in classroom-level segregation and can be unattainable to many students in need due to admissions tests and limited placement options. ${ }^{96}$ Magnet school programs are often too small to impact district-wide desegregation efforts, ${ }^{97}$ and too expensive to operate on a broad scale. ${ }^{98}$

\section{Managed Choice Options}

Another choice-based strategy districts have used for desegregation is a hybrid of magnet-type schools, student assignment, and geographic boundaries. These types of plans, known usually as either "managed choice" or "controlled choice," direct students to particular school options depending on where students live and the demographic targets for each school. ${ }^{99}$ Families apply for school options, often applying to more than one school on a tiered list, and then are assigned to a school according to their preference and on how their children's

\footnotetext{
${ }^{93}$ See $i d$. at 226 (explaining that "as desegregation goals were de-emphasized, a number of magnet schools became less effective in attracting diverse groups of students."). See also Nelson, supra note 38, at 47 ("The decrease in the 'magnetizing' effect of magnet schools has been linked to the federal government's decreased emphasis on desegregation."). The mission of magnet schools "has shifted considerably from its historical focus on racial desegregation." TEFERA ET AL., supra note 38, at 19; see id. "Stagnant funding and a move away from raceconscious desegregation efforts in both federal policy and judicial decision-making may account for some of the shifts in magnet priorities.").

${ }_{94}$ See Holley-Walker, supra note 15, at 448 ("Despite this reliance on magnet schools as a desegregation mechanism, the schools' effectiveness in promoting racial integration may be waning due to a lack of funding."). Ironically, despite some proven successes, funding decreased while funding for less proven choice options has increased. See Nelson, supra note 38, at 47 ("Notwithstanding their proven track record, magnet school funding has decreased while charter school funding has increased.").

${ }^{95}$ Kimberly Jenkins Robinson, The Constitutional Future of Race-Neutral Efforts to Achieve Diversity and Avoid Racial Isolation in Elementary and Secondary Schools, 50 B.C. L. REV. 277, 341 (2009) ("Researchers debate the ability of magnet schools to serve as an effective integration tool."); see also Steve Brandt, Minneapolis Finds Magnet Schools Don't Work to Desegregate, MinNEAPOLIS STAR TRIB. (Apr. 19, 2014), http://www.startribune.com/minneapolis-finds-magnet-schools-don-t-work-to-desegregate/255836901/ (reporting that the Minneapolis school district found little benefit from the district's use of magnet schools both in terms of desegregation and student achievement).

${ }^{96}$ See Heeren, supra note 88, at 183 ("[Magnet schools] often result in classroom-level segregation and limit access to the most in-need, under-educated students of any racial background.") (citing Mark G. Yudof et al., Educational Policy and the Law 414 (West 2002)).

${ }^{97}$ See Martha Minow, Confronting the Seduction of Choice: Law, Education, and American Pluralism, 120 YALE L.J. 814, 826 (2011) ("As a device to promote racial balance in previously segregated or racially isolated schools, magnet programs sometimes produce diverse enrollments while reducing diversity in the nonmagnet schools.") (internal citations omitted).

${ }^{98}$ See Heeren, supra note 88 , at 183 ("[T] hey are costly and would be exceedingly difficult to apply to a degree that would significantly desegregate or improve the diversity of an entire school district."); Minow, supra note 97, at 826 ("In addition, they may seem too expensive to offer a feasible model for other schools or beyond the remedial power of a desegregation court.").

${ }^{99}$ See Frankenberg \& Siegel-Hawley, supra note 80, at 226 (pointing out that this gives the program a combination of the benefits of magnet-type style programs "with elements of a mandatory student assignment plan.") (internal citations omitted).
} 
enrollment will impact the demographics of the particular school. ${ }^{100}$ The most sophisticated plans poll parents ahead of time, asking them what subject matters or pedagogical approaches would attract them to attend a school farther away so that districts can design schools that might attract underrepresented students to particular schools. ${ }^{101}$ Unlike mandatory desegregation plans of the 1960s, controlled choice plans originated largely outside of the South. ${ }^{102}$

The results of controlled choice have been mixed. The Cambridge School District in Massachusetts created the first city-wide controlled choice integration plan. ${ }^{103}$ It began in 1980 as a race-based plan and subsequently changed to socioeconomic status 15 years ago, requiring schools to be within plus or minus ten percentage points of the district's overall average eligibility for free or reduced-price lunch. ${ }^{104}$ Although the district has had some difficulties in keeping all of its schools in compliance and has had a significant drop in enrollment over the years, ${ }^{105}$ a recent study concluded that "for the most part, the controlled choice plan was successful in achieving diversity in the district's schools." ${ }^{106}$ Perhaps more importantly, Cambridge has had good results in academic achievement, including significantly higher graduation rates for its low-income students of color than comparable students statewide. ${ }^{107}$

A nearby district with a similar voluntary desegregation program is Lynn,

${ }^{100}$ In this way districts can manage (or control) the diversity of individual schools while still providing some degree of choice to families as to where to send their children. See id. at 226 ("School systems employing managed choice. . consider how assignment decisions will affect the student body composition of each school."). Controlled choice programs may also take account of "sibling enrollment, geographic proximity, student achievement, socioeconomic balance, and density." Id. at $226 \mathrm{n} .42$. In Cambridge, for example, "[s]chool assignments first aim to match families to their choices of school; however family choice is balanced against the district's interest in creating equitable schools." Cambridge Public Schools, About Controlled Choice, available at

http://www.cpsd.us/departments/frc/making_your_choices/about_controlled_choice (hereafter "CPS Website"). One of the benefits listed is that "Students have the opportunity to get outside of their neighborhood and experience the rich diversity of our community." Id.

${ }^{101}$ Richard A. Kahlenberg, From All Walks of Life: New Hope for School Integration, AMERICAN EDUCATOR 10 (2012), available at https://www.aft.org/sites/default/files/periodicals/Kahlenberg.pdf.

${ }^{102}$ See Frankenberg \& Siegel-Hawley, supra note 80, at 227 ("By the time limited desegregation spread to the North and West, choice had become more common--making voluntary or semi-voluntary desegregation measures popular[,l" partly due to the "chilling effect" of the Milliken decision on trying to mandate interdistrict programs.).

${ }^{103}$ Joseph P. Viteritti, Choosing Equality: Religious Freedom and Educational Opportunity Under Constitutional Federalism, 15 YALE L. \& POL'Y REV. 113, 171 (1996).

${ }^{104}$ See Kahlenberg, supra note 101, at 10; see also CPS Website, supra note 100 ("Controlled Choice began in 1980 when the Cambridge School Committee voted to desegregate the schools by moving away from a neighborhood schools model."); TEFER A ET AL., supra note 38, at 32 (discussing the change in Cambridge from a race-based to socioeconomic-based focus on diversity).

${ }^{105}$ Frankenberg \& Siegel-Hawley, supra note 80, at 236. The district took steps to identify potential reasons for the drop in enrollment, including a survey of parent attitudes and various outreach efforts to families. Id. Their efforts paid off to some extent as enrollment increased, but at the cost of having nearly $40 \%$ of its schools end up outside compliance with socioeconomic diversity guidelines and a slight decline in racial balance. Id.

${ }^{106}$ Jennifer B. Ayscue, Alyssa GreenBerg, John Kucsera \& Genevieve Siegel-Hawley, C.R. Project, LOSING GROUND: SCHOOL SEGREGATION IN MASSACHUSETTS 7 (2013). The district, however, has had an increase in heavily racially isolated schools. Id.

${ }^{107}$ Kahlenberg, supra note 101, at 12; see also Ayscue et al., supra note 106, at 7 (finding that "low-income students in Cambridge outperform their counterparts in the state, and $90 \%$ of low-income students in Cambridge are graduating compared to $65 \%$ of low-income students in the state."). However, the district "was not as successful in improving overall student achievement and narrowing gaps among students of different races and socioeconomic classes." Id. 
Massachusetts. ${ }^{108}$ Under its Voluntary Plan for School Improvement and the Elimination of Minority Isolation, school admissions and student transfers in Lynn Public Schools must consider both the race of the student and the racial balance at the receiving school. ${ }^{109}$ To maintain diversity throughout all of the schools in the district, students may not make a "segregative transfer," where their enrollment "would exacerbate racial imbalance in the sending or receiving school" (e.g., a white student may not transfer to a school already predominantly white). ${ }^{110}$ Importantly, the program in Lynn goes beyond mere balancing of students, including curricular and professional development specifically designed to improve interracial relations. ${ }^{11}$ The drafters of the plan "recognized that integration involves more than race-conscious school assignment policies, more than simply the mixing of students of different racial backgrounds."112 The plan also includes important financial balancing to maintain quality funding standards in all of its schools. ${ }^{113}$

The results in Lynn with respect to school segregation, however, have been disappointing. A recent study concludes that Lynn is resegregating. ${ }^{114}$ Its population of white students dropped from $64.5 \%$ in 1989 to less than $25 \%$ in 2010 , which has contributed to the levels of segregation in the schools. ${ }^{115}$ Now $13 \%$ of Lynn's schools are $90 \%$ or more students of color. $^{116}$

In California, one district has been able to maintain a variety of desegregation policies for more than forty years. ${ }^{117}$ After a number of various managed choice programs, the Berkeley Unified School District now relies mostly on neighborhood composition and family choice to promote diversity. ${ }^{118}$ Among other features, the core of Berkeley's plan is assigning diversity

\footnotetext{
${ }^{108}$ Both Lynn and Cambridge are part of the greater Boston metropolitan area. See GREATER BOSTON METRopolitan AREA PlanNIng Council, ANNUAL REPORT 15 (2015) (on file with author).

1092017 LyNN PUBliC SCHOOLS POLICY MANUAL, Section J, File JF pp.1-5 (on file with author).

${ }^{110}$ Comfort v. Lynn Sch. Dist., 418 F.3d 1, 8 (1st Cir. 2005), abrogated by Parents Involved, 402 U.S. 701

${ }^{111}$ Comfort v. Lynn Sch. Comm., 263 F. Supp. 2d 209, 229 (D. Mass. 2003), amended by 283 F. Supp. 2 d 328 (D. Mass. 2003), and aff'd en banc, 418 F.2d 1 (lst Cir. 2005) (noting how "the Plan included substantial curricular innovations designed to ensure positive racial interaction; training and development of staff to address the challenges of teaching children of diverse backgrounds; programs that would create opportunities for positive interaction among students, school personnel and parents from different racial and ethnic groups, which are not normally found within regular school programming; integrated leadership opportunities and training to give students the skills necessary to deal effectively with racial tension and conflict, etc."). See also Epperson, supra note 25 , at 210-11 (by including such "holistic integrative measures...the race-conscious program voluntarily adopted by the Lynn district actually attempts to alter the racial hierarchy, because it looks to racial balancing as well as the quality of interaction between students of different races").

112 Comfort, 263 F .Supp.2d at 229.

${ }^{113}$ Id. at 229-30; see also Epperson, supra note 25, at 211 ("Moreover, the plan combines these integrative remedies with expenditures to improve physical facilities and to develop and standardize curricular offerings ... [to] explicitly address[] the ideal of integration and the necessity for the provision of adequate institutional resources in the face of entrenched, systemic racial inequities.") (internal citations omitted).

114 AYSCUE ET AL., supra note 106, at 36.

${ }^{115} \mathrm{Id}$. at 37.

${ }^{116} \mathrm{Id}$. at 66.

${ }^{117}$ See TEFERA ET AL., supra note 38, at 27 ("Berkeley Unified has voluntarily implemented desegregation plans for more than four decades.").

${ }^{118}$ See Meredith P. Richards, Kori J. Stroub, Julian Vasquez Heilig, and Michael R. Volonn, Achieving Diversity in the Parents Involved Era: Evidence for Geographic Integration Plans in Metropolitan School District, 14

BERKELEY J. AFR. AM. L. \& POL'Y 65, 69-71 (2012) (tracing the long history of Berkeley's desegregation efforts); Lisa Chavez \& Erica Frankenberg, C.R. Project, The ChIEF Just. Earl Warren InSt. On RaCE, Ethnicity \& DiVERSITY, INTEGRATION DEFENDED: BERKELEy UNIFIED's STRATEGY TO MAINTAIN SCHOOL DivERSITY 3-5
} 
scores not to individual students but to the neighborhoods in which they live. The diversity score is based on neighborhood-wide measures of household incomes, education level of adults, and the racial composition of the neighborhood's children. ${ }^{119}$

The combination of these factors is unique not just because it includes a variety of demographic information, but because it assigns students based on their neighborhood's demographics, not their own individual characteristics. ${ }^{120}$ As a result, all students within each neighborhood are assigned identical diversity indices, regardless of their own racial identity or socioeconomic status. ${ }^{121}$ In doing so, the district is essentially exploiting residential segregation to desegregate its schools. ${ }^{122}$ Despite having "substantial residential segregation," 123 Berkeley has had success in maintaining diversity in its schools under this plan. ${ }^{124}$ The Berkeley model remains an important template for other districts interested in desegregating their schools, particularly in a post-Parents Involved world. ${ }^{125}$

\section{Limits to Relying on Voluntary Choice Plans}

While the three districts highlighted above have shown some successes with relying on choice-based plans, school choice generally has a more checkered past. School choice has always had a complicated relationship with efforts to desegregate schools. ${ }^{126}$ Early choice programs were used in the South to avoid desegregation. ${ }^{127}$ Private schools and public school

(2009), available at http://www.berkeleyschools.net/wp-

content/uploads/2016/02/BUSD_Integration_Defined_Civil-Rights-Project.pdf (detailing the "series of innovative desegregation efforts in a district of substantial diversity").

119 See id. at 6 ("The composite diversity categories...are based on household incomes, education attainment of adults 25 and older . . . and percentage of students of color enrolled in K-5 at BUSD in each planning area. Each of these diversity components (race, income, and education) is weighted evenly to formulate the final diversity composite.") (internal citations omitted).

${ }^{120}$ See id. ("All students living in a particular planning area are assigned that area's diversity category for assignment purposes, regardless of the race-ethnicity, income, and levels of adult education in their individual households.").

${ }^{121}$ As the California Court of Appeals found in upholding the constitutionality of the plan, "[e]very student within a given neighborhood receives the same treatment, regardless of his or her individual race." Am. Civil Rights Found. v. Berkeley Unified Sch. Dist., 90 Cal. Rptr. 3d 789, 792 (Ct. App. 2009). Because the plan does not "show partiality, prejudice, or preference to any student on the basis of that student's race," the plan does not violate constitutional or other legal restrictions on the use of race. $I d$. at 797. Indeed, in the court's opinion, "[a]ll students in a given residential area are treated equally-regardless of the student's individual race or other personal characteristics." Id.

${ }^{122}$ See Richards et al., supra note 118, at 71-72 ("Inasmuch as they use neighborhood racial/ethnic and socioeconomic characteristics as proxies for individual student race/ethnicity, geographic integration plans are thus designed to achieve integration by exploiting the legacy of segregation."). In relying on neighborhood characteristics, the district is relying on the reasonable "assumption that neighborhood characteristics are accurate predictors of the students living in those neighborhoods." Id. at 71.

${ }^{123}$ CHAVEZ \& FRANKENBERG, supra note 118 , at 11.

124 See Richards et al., supra note 118, at 71 (concluding that "our analysis of data . . reveals that Berkeley's [school] segregation rates have remained extremely low since shifting from a race-based to a geography-based integration plan"); CHAVEZ \& FRANKENBERG, supra note 118, at 15 (finding that "in general, the [school] integration across the district is fairly high").

125 See ChAVEZ \& FRANKENBERG, supra note 118, at 25 ("Other communities fearful that no option to prevent resegregation remains should seriously consider this model."); see also infra notes 190-99 and accompanying text (describing the impact of Parents Involved on district decision-making concerning the use of race).

${ }^{126}$ See Nelson, supra note 38, at 45 ("School choice policies and efforts towards achieving civil rights in education have long been at odds with each other.").

${ }^{127}$ Indeed, the notion of choice conjures up its ugly past as a tool to undermine desegregation efforts. See powell, 
transfer options sprang up after the Brown decision to provide escape hatches for white students from court-ordered desegregation. ${ }^{128}$ White students received public vouchers to attend private "segregation academies" specifically to frustrate desegregation. ${ }^{129}$ In some cases, public schools were shut down for years at a time while white students were able to enroll in all-white private schools with public funds. 130

The next wave of problematic choice programs is exemplified by the freedom of choice plan confronted by the Court in Green v. County School Board of New Kent County. ${ }^{131}$ In Green, the local district relied entirely on a "freedom-of-choice" plan where African American students could opt to enroll in white schools in order to desegregate them. ${ }^{132}$ The Court found that the district needed to find a more "realistic" approach. ${ }^{133}$ According to the Court, freedom-of-choice plans, such as the one in New Kent County, "simply burden[ed] children and their parents with a responsibility [that should be] placed squarely on the School Board." 134 Courts also sometimes saw through the attempt by districts in using such choice programs to continue to promote allwhite segregated private schools. ${ }^{135}$ Imposing obligations on African American students to

supra note 18, at 673 ("Choice has a particularly suspect history in the school context. Choice was used after Brown as many southern school systems tried to avoid the reaches of Brown, maintaining the subjugation of African Americans under various choice schemes."); Minow, supra note 97, at 823 (discussing how "freedom of choice" plans became "a euphemism for resurgent racial separation" because districts simply allowed white students to "opt out of desegregated schools" in favor of all-white private schools).

${ }^{128}$ See Minow, supra note 9, at 821 ("[P]rivate schooling became an avenue for circumventing court-ordered school desegregation in the wake of Brown. Plans ostensibly allowing students to transfer across 'public schools'-introducing the phrase to educational policy--did the same, but produced essentially no movement between historically black and historically white schools.").

${ }^{129}$ See Frankenberg \& Siegel-Hawley, supra note 80, at 223 ("Public vouchers to private segregation academies, freedom of choice plans, and open enrollment all serve as early examples of school choice used to thwart desegregation."); see also Nelson, supra note 38, at 45-46 ("Immediately after the Court's seminal decision requiring educational equity, some states and districts used school choice policies to stymie the progress of school desegregation.").

${ }^{130}$ In 1959, Prince Edward County in Virginia voted to stop funding the public schools, effectively closing the schools. Minow, supra note 97, at 823; see also Griffin v. Cty. Sch. Bd., 377 U.S. 218, $221-26$ (1964) (discussing the history of the county's efforts). White students were able to attend all-white private schools, using scholarship grants from the white community and additional county funds to support these schools. Minow, supra note 97, at at 823. "[M]ost of the county's 1,700 African American children had no educational opportunities for five years." Id. The Supreme Court eventually intervened and found that "closing the Prince Edward schools and meanwhile contributing to the support of the private segregated white schools that took their place denied petitioners the equal protection of the laws." Griffin, 377 U.S. at 232.

${ }^{131}$ Green v. Cty. Sch. Bd. of New Kent Cty., 391 U.S. 430 (1968).

${ }^{132}$ White students were also given the option of enrolling in all-African American schools, but after three years, not one white student did so. Green, 391 U.S. at 441. Principles of market economics emerged at that time as a justification for allowing students to be able to choose wherever they went to school. See Minow, supra note 97, at 821 ("The use of school choice to sidestep racial desegregation exploited the rationale for choice as a vehicle for individual liberty and market-propelled competition that emerged in the 1950s and 1960s."). Just one year after Brown, economist Milton Friedman advanced a consumer-sovereignty and market rationale for using public funds to give parents vouchers, enabling them to select among public and private schools and harness competition as a motor for school improvement. Id. at 822. (citing Milton Friedman, The Role of Government in Education, in ECONOMICS AND THE PUBLIC INTEREST 123 (Robert A. Solo ed., 1955)).

${ }^{133}$ See Green, 391 U.S. at 442 (requiring the district to "fashion steps which promise realistically to convert promptly to a system without a "white' school and a 'Negro' school, but just schools").

${ }^{134}$ Id. at 441-42.

${ }^{135}$ See, e.g., Poindexter v. Louisiana Fin. Assistance Comm'n, 275 F. Supp. 833, 835 (E.D. La. 1967), aff'd per curiam, 389 U.S. 571 (1968) (finding that each of these choice programs "whether its objective was obvious or nonobvious, was designed to provide a state-supported sanctuary for white children in flight from desegregated 
remedy school segregation was particularly problematic "[i]n the midst of violence, intimidation and powerful opposition." 136

Despite their past use to maintain segregation, school choice programs eventually became a favored tool of desegregation. Instead of providing exit options for white families, the desegregation choice options endeavored to persuade white families to enroll their children in previously segregated environments. ${ }^{137}$

Even choice plans specifically designed to desegregate, however, were often unsuccessful. Disparities in access and "the continuing patterns of unequal access to test preparation and information used in the school choice systems" favored white and wealthy families in this process. ${ }^{138}$ One particular choice option-charter schools-lead to increased levels of segregation in schools. ${ }^{139}$

\section{B. Geographic-based Options}

1. Attendance Zones

public schools ... [and] to continue segregated education in Louisiana by providing state funds for the establishment and support of segregated, privately operated schools for white children"); see also Frankenberg \&Siegel-Hawley, supra note 80 , at 224 ("Despite these attempts to use choice to minimize the extent of desegregation, the combination of the executive, legislative, and judicial branches of the federal government remade many districts across the South by cutting off funding to districts that were not in compliance with court orders or settlement agreements. For a time at least, using choice to avoid more widespread, comprehensive efforts at desegregation ended."); Nelson, supra note 38, at 46 ("F]ederal legislation] [also] forced districts to value desegregation over school choice; prior to these federal acts, school choice had primarily been used to perpetuate segregation.").

${ }^{136}$ Frankenberg \& Siegel-Hawley, supra note 80, at 223; see also Nelson, supra note 38, at 57 ("Freedom of choice plans were also notoriously unsuccessful at integrating schools since the plans placed the onus of enforcing Brown's promise on those families that Brown sought to protect from discrimination and retribution for seeking to desegregate schools."). As Paul Gewirtz wrote in the midst of the desegregation boom thirty years ago:

Because of the nature of the past discrimination, effective remedies for individuals cannot be furnished by purely individualistic solutions such as letting students choose their schools one-by-one; individualistic solutions misunderstand the remedial right. A black child's remedial right is not a right to attend the previously white school; it is a right to attend a desegregated school - an institution that is not racially identified, an institution whose attendance patterns do not reflect the regime of past de jure segregation, an institution that is not an element of a segregated system. That individual right simply cannot be fully achieved in isolation from what happens to other children: the effectuation of individual rights requires coordinated systemic action.

Paul Gewirtz, Choice in the Transition: Desegregation and the Corrective Ideal, 86 Colum. L. Rev. 728, 751 (1986).

${ }^{137}$ See Minow, supra note 97, at 825 ("School system designers sought to harness the appeal of 'choice' in a kind of 'soft paternalism,' enticing white parents to choose public urban schools by endowing them with special programs and drawing black, Hispanic, and immigrant students out of their neighborhoods to these special schools.").

${ }^{138}$ See id. at 828 ("Unequal access to information about school choice options affects admissions even at those schools without competitive testing. Criteria such as mandatory parental involvement and inadequate transportation skew enrollments in specialized schools toward disproportionately white and wealthier families.").

${ }^{139}$ See William J. Glenn, School Segregation in Jefferson County and Seattle: The Impact of the Parents Involved Ruling and District Actions, 63 CLEV. ST. L. Rev. 297, 315 (2015) (citing E. Frankenberg, G. Siegel-Hawley, \& J. Wang, Choice Without Equity: Charter School Segregation, 19 EDUC. POL'Y ANALYSIS ARCHIVES 1 (2011)); W. J. Glenn, A Quantitative Analysis of the Increase in Public School Segregation in Delaware: 1989-2006, 46 URBAN EDUC. 719, 722, 736-37 (2011); see also Stephen Samuel Smith, Still Swimming Against the Resegregation Tide? A Suburban Southern School District in the Aftermath of Parents Involved, 88 N.C. L. Rev. 1145, 1184-85 (2010) (noting that the paucity of charter schools in Rock Hill contributes to its ability to maintain district-wide diversity); see also supra note 38 and accompanying text (collecting studies on impact of charter schools on segregation). 
Attendance zone boundaries, which often determine where children go to school, have been used both to segregate and desegregate schools. ${ }^{140}$ School choice programs were not the only means through which white students avoided desegregated schools. For example, in Columbus Board of Education v Penick, ${ }^{141}$ the Supreme Court confronted and eventually prohibited "intentionally segregative" uses of various attendance zone policies that maintained racial segregation. ${ }^{142}$ In that case, such practices included optional attendance zones that allowed white students to avoid desegregated schools located near the homes of white students ${ }^{143}$ and gerrymandered zones that resulted in white students being bused past their neighborhood school to a "whiter" school. ${ }^{144}$ According to the Court, these boundary policies were "a classic example of a segregative device designed to permit white students to escape attendance at predominantly black schools." 145

On the other hand, an example of an attempt to pursue racial desegregation, rather than segregation, through attendance zone boundaries is the school attendance zone plan challenged in Doe v. Lower Merion School District ${ }^{146}$ In Lower Merion, a Pennsylvania school district implemented a race-conscious attendance zone plan designed, in part, to promote diversity across the district. ${ }^{147}$ The adopted plan featured a "feeder pattern" that would draw African American students from two predominantly African American neighborhoods into different high schools rather than the same high school. ${ }^{148}$

The Third Circuit Court of Appeals upheld the plan because the plan "d[id] not select students based on racial classifications" nor " $\mathrm{d}[\mathrm{id}]$ it have a racially discriminatory purpose." 149 Instead, like Berkeley's controlled choice plan, ${ }^{150}$ the plan targeted neighborhoods rather than individuals. ${ }^{151}$ Other districts have found similar efforts to be successful in promoting desegregation, ${ }^{152}$ and the Supreme Court has approved such use of attendance zones. ${ }^{153}$

\footnotetext{
${ }^{140}$ Drawing attendance zone boundaries is required by nearly all school districts in order to sort out where students will attend schools. See TEFERA ET AL., supra note 38, at 18 (describing "zoning" as "one of the tools used by almost all school district with more than one school at a given grade level"). Even aside from diversity purposes, districts design zones that are "non-contiguous" to intentionally draw students from different parts of the district to the same school. Id.

${ }^{141}$ Columbus Board of Education v Penick, 443 U.S. 449 (1979).

${ }^{142} I d$. at 461-62. The Court specifically struck down the segregative use of optional attendance zones, discontiguous attendance areas, and boundary changes, among other practices.

${ }^{143}$ Id. at $461 \mathrm{n} .8$.

${ }^{144} \mathrm{Id}$. at $461 \mathrm{n} .9$. The Court also found that for one area on the west side of the city containing three white schools and one black school the Board had altered the lines so that white residential areas were removed from the black school's zone and black students were contained within that zone. Id. at $461 \mathrm{n} .10$.

${ }^{145} I d$. at $461 \mathrm{n} .8$ (internal citations omitted).

${ }^{146} 665$ F.3d 524 (3d Cir. 2011).

${ }^{147}$ See id. at 530-38 (discussing the legislative history of the plan). Importantly, the court found that "references to diversity in the context of this facially neutral policy implied that decision-makers did not want the selected plan to have a racially disproportionate impact." Id. at 554.

${ }^{148} I d$. at $536-38$.

${ }^{149}$ See id. at 529 ("We hold that the plan here passes constitutional muster because it does not select students based on racial classifications, it does not use race to assign benefits or burdens in the school assignment process, it does not apply the plan in a discriminatory manner, and it does not have a racially discriminatory purpose. Strict scrutiny does not apply.").

${ }^{150}$ See supra notes 117-124 and accompanying text (describing the geographic-based plan used in Berkeley, California).

${ }^{151}$ See 665 F.3d at 545 (Lower Merion's' plan "is facially race neutral, assigning students to schools based only on the geographical areas in which they live. The Plan, on its face, neither uses racial classification as a factor in student assignment nor distributes any burdens or benefits on the basis of racial classification."). The issue for the
} 
As a cautionary note, however, reliance on attendance zone boundaries on their own may be insufficient for integrating many school districts. For example, districts already substantially racially isolated will have little impact from new attendance zone boundaries. ${ }^{154}$ Attendance zone boundaries can have little effect on "white flight" from the district. ${ }^{155}$ They may also help destabilize neighborhoods. ${ }^{156}$ Lastly, there are often insurmountable political issues that undermine a district's capacity to undertake necessary adjustments to attendance zone boundaries over time. ${ }^{157}$

court was that targeting African American neighborhoods was not the same as targeting individual students based on race; Stephen Menendian, What Constitutes a 'Racial Classification'?: Equal Protection Doctrine Scrutinized, 24 TEMP. POL. \& CIV. RTS. L. REV. 81, 94 (2014) (discussing in detail the Lower Merion decision and concluding that the difference for the court, in the end, was that the district was using a race-conscious assignment policy that only considers race in a generalized way, rather than at an individualized level).

${ }^{152}$ See id. at 94 (discussing similar plans in Jefferson County, Kentucky and Berkeley, California and noting that both survived legal challenges using the same approach as Lower Merion); see also Robinson, supra note 95, at 339-40 (2009) (reporting the successes of a similar approach in Rock Hill, South Carolina, which successfully reduced racial isolation in some schools and achieved integration in others at both the high school and elementary levels).

${ }^{153}$ See e.g. Davis v. Bd. of School Comm'rs, 91 S. Ct. 1289, 1292 (1971) ("A district court may and should consider the use of all available techniques including restructuring of attendance zones and both contiguous and noncontiguous attendance zones."); see also Swann, 402 U.S. at 8 (discussing attendance zones "shaped like wedges of a pie, extending outward from the center of the city to the suburban and rural areas of the county in order to afford residents of the center city area access to outlying schools"). More recently, the Court in Parents Involved explicitly endorsed the sort of plan approved in Lower Merion. sSee infra notes 203-206 and accompanying text (explaining how the controlling opinion of Justice Kennedy includes such race-conscious boundary drawing as a permissible strategy for desegregation).

${ }^{154}$ See Heeren, supra note 88, at 186 ("The biggest problems with this strategy, however, are that it remains ineffective in racially isolated communities, would likely be controversial within a heterogeneous community, and might require gerrymandered attendance zones that force students to attend schools much further away than their traditional neighborhood schools."); Richard Kahlenberg, How to Keep Brown Alive, SLATE (June 29, 2007), $\mathrm{http} / / / \mathrm{www}$.slate.com/id/2169443 (arguing that redrawing attendance zones will have little effect in a heavily segregated district); but see Michael B. de Leeuw et al., Residential Segregation and Housing Discrimination in the United States: Violations of the International Convention on the Elimination of All Forms of Racial Discrimination 11 (2007), delivered to the Office of the United Nations High Commissioner for Human Rights (2007), http:// www2.ohchr.org/english/bodies/cerd/docs/ngos/usa/USHRN27.pdf (noting that attendance zone planning can have a positive impact on a district because it eliminates "white enclaves" and allows parents to live anywhere in the district and know that their child will attend a desegregated school).

${ }^{155}$ Salvatore Saporito \& Deenesh Sohoni, Coloring Outside the Lines: Racial Segregation in Public Schools and Their Attendance Boundaries, 79 Soc. EDUC. 81, 96 (2006) (finding that white students tend to leave the public schools at higher rates when the district racially balances school attendance boundaries).

${ }^{156}$ Robinson, supra note 95 , at 340 (finding that research on redrawing attendance zones to achieve diversity suggests that "some districts will find this approach effective, though others may find that it has adverse effects such as destabilizing neighborhoods").

${ }^{157}$ See Halley PotTer \& Kimberly Quick, A New WACE OF SCHOOL InTEGration: Districts AND Charters Pursuing SOCIOECONOMIC Diversity, The CentuRY Foundation (Feb. 9, 2016), https://tcf.org/content/report/anew-wave-of-school-integration ("School boundary decisions are also almost always politically contentious .... Bringing questions about socioeconomic and racial integration into the conversation can unleash a host of parent concerns and anxieties."). In Eden Prairie, Minnesota, for example, the decision to redraw elementary school boundaries in order to create more racially and socioeconomically integrated schools in 2010 led to community backlash that culminated with the ousting of the superintendent who had led those efforts; Greg Toppo and Paul Overberg, Diversity in the Classroom: Sides Square Off in Minnesota, USA TODAY (November 25, 2014), http://www.usatoday.com/story/news/nation/2014/11/25/minnesota-school-race-diversity/18919391/. 


\section{Metropolitan-wide Solutions}

Desegregation efforts confined within the boundaries of a single school district like attendance boundary drawing and district-wide magnets are only effective in limited circumstances. ${ }^{158}$ Most central cities are already too racially isolated for such intra-district programs to have much effect. It is no surprise then that only a very small number of "stably integrated schools" are located in the central cities. ${ }^{159}$ Studies show that there is more racial segregation in schools between districts than within districts. ${ }^{160}$ By one estimate, as much as $69 \%$ of segregation in metropolitan areas is due to segregation between districts. ${ }^{161}$ In the South, while there have been large declines in within-district segregation in metropolitan areas from 1970 to 2000 , between-district segregation doubled during that same time period. ${ }^{162}$ So substantial is the impact of interdistrict demographic disparities that some of the progress made by court orders to eliminate segregation within districts have been offset by rising between-district segregation. ${ }^{163}$

Unfortunately, the Supreme Court prohibited metropolitan-wide judicial remedies to regional segregation more than forty years ago in Milliken v. Bradley. ${ }^{164}$ According to the Court, interdistrict remedies would violate the sanctity of "local control," even if the Court's decision would render the city schools hopelessly segregated. ${ }^{165}$ Subsequent court decisions have locked in the idea that interdistrict remedies by future courts are highly unlikely to address city school segregation. ${ }^{166}$

${ }^{158}$ Indeed, the highlighted districts discussed infra were smaller cities with school populations around 10,000 students.

${ }^{159}$ Erica Frankenberg, School Segregation, Desegregation, and Integration: What Do These Terms Mean in a PostParents Involved in Community Schools, Racially Transitioning Society?, 6 SEATTLE J. FOR SOC. JUST. 533, 554 (2008) (finding that stably integrated schools were disproportionately less likely to be found in large central cities: only $5 \%$ of stably integrated schools were in these cities).

${ }^{160}$ See ClotFel TER, supra note 50, at 73 (2004); see also Chemerinsky, supra note 17, at 634 ("American schools would be $60 \%$ less segregated if inter-district remedies were possible.").

${ }^{161}$ See ClOTFELTER, supra note 50, at 73 (finding that the between-district component of segregation was .225 out of total segregation among all metropolitan areas of .326.).

${ }^{162}$ See id. at 63; see also LOGAN \& OAKLEY, supra note 34, at 22 ("The clear conclusion is that the failure to achieve more even racial balance across school districts in much of the country has sharply limited progress toward equal educational opportunity by placing black students disproportionately in high-poverty schools.").

${ }^{163}$ See Frankenberg \& Le, supra note 71, at 1028 (finding that "some of the judicial efforts to eliminate withindistrict segregation have been offset by rising between-district segregation. Other analyses have confirmed a high percentage of segregation due to between-district differences.").

${ }^{164}$ Milliken v. Bradley, 418 U.S. 717 (1974).

${ }^{165}$ See id. at 741 ("No single tradition in public education is more deeply rooted than local control over the operation of schools"). The Court explicitly acknowledged the inevitability of racially isolating the Detroit public schools, noting that the lower court had already concluded that "any Detroit-only segregation plan will lead directly to a single segregated Detroit school district overwhelmingly black in all of its schools, surrounded by a ring of suburbs and suburban school districts overwhelmingly white in composition." Id. at 739 (citations omitted). For a thorough critique of the Court's reasoning by a former judge of the United States Court of Appeals for the Sixth Circuit Court and the general counsel for the NAACP-LDF during the Milliken litigation, see Nathaniel R. Jones, Milliken v. Bradley: Brown's Troubled Journey North, 61 FoRDHAM L. REV. 49, 50 (1992) ("It is futile for legal scholars to continue to try to make sense out of the majority holding without taking into account that the Court departed from precedent and avoided logic and reason. To harness or to limit the remedial power of the district court, after it had already found violations of the Constitution, was simply to elevate political concerns over those of the Constitution.").

${ }^{166}$ See, e.g., Missouri v. Jenkins, 515 U.S. 70, 97-98 (1995) (striking down a plan to improve Kansas City, Missouri, schools by making the city schools more attractive to the surrounding suburbs). In Missouri v. Jenkins, "[T]he Court found that the purpose motivating these seemingly intra-district remedies exceeded the scope of the constitutional 


\section{III: Moving Beyond Traditional Desegregation: Additional StRATEgiES to INTEGRATE SCHOOLS}

Previous desegregation plans, such as those described above, suffer from four basic limitations. First, such plans are typically confined to the boundaries of a single school district, which restricts the ability of districts to meaningfully integrate schools, particularly in highly segregated urban centers. Second, desegregation plans must carefully navigate the legal constraints placed on using race as a factor by the Court in Parents Involved. Third, the vast majority of desegregation plans focus exclusively on the demographic composition of schools, most typically balancing the number of students of color and the number of white students. Fourth, such plans have limited their reach to education policy only and have failed to consider connections to housing policy and entrenched patterns of neighborhood-level segregation.

\section{A. Beyond Boundaries: City Districts Cannot Integrate on Their Own}

\section{Interdistrict Plans Are Most Stable}

Given the demographic reality in most city districts, desegregation may be nearly impossible without metropolitan-wide options. Indeed, desegregation "may be off the radar in these school districts because the racial demographics of the school districts do not lend themselves" to an intra-district option. ${ }^{167}$ Because interdistrict remedies are off the table, desegregation by courts and other means largely left the nation's major cities untouched (and in some cases even more segregated). ${ }^{168}$

But interdistrict plans do not require the courts. Despite the Court's prohibition, there have been school districts (and regional governing authorities) that have managed to implement metropolitan-wide desegregation plans on their own, and the results are compelling. The desegregation plans that did include mandatory metropolitan desegregation showed the greatest stability of enrollments by race. ${ }^{169}$ Metropolitan-wide plans work because they take away exit options for white families who try to leave districts before they can integrate. Interdistrict options help overcome such white flight. ${ }^{170}$ In addition, they help keep the neighborhoods stable. ${ }^{171}$ Of

violation because they were effectively interdistrict in nature." Frankenberg \& Le, supra note 71, at 1031; see also Holley-Walker, supra note 40, at 906 ("Since the Supreme Court's decision in Milliken v. Bradley, the availability of interdistrict remedies has been severely limited.").

167 See id. at 892.

${ }^{168}$ See LOGAN \& OAKLEY, supra note 34, at 24 (finding that segregation across schools in the large metropolitan centers overall has remained much higher than segregation in the average school district).

${ }^{169}$ See Gary Orfield, Metropolitan School Desegregation: Impacts on Metropolitan Society, 80 MINN. L. REV. 825 , 831 (1996) ("[T]he most extensive desegregation plans, covering entire urbanized counties, have shown by far the highest levels of desegregation and have produced the nation's most stable districts in their percentage of white enrollment.").

${ }^{170}$ See powell, supra note 47, at 760 ("Metropolitan-wide programs are comparatively more successful in part because they indirectly address the issue of white flight by making it difficult for white families to escape attempts to integrate schools."). Limiting ways for white families to leave the district can be a critical factor in preserving desegregation plans. Rock Hill, South Carolina, has maintained its desegregation largely because of "a relative paucity of exit options from the district." Stephen Samuel Smith, Still Swimming Against the Resegregation Tide? A Suburban Southern School District in the Aftermath of Parents Involved, 88 N.C. L. REV. 1145, 1184 (2010).

${ }^{171}$ Myron Orfield, Regional Strategies for Racial Integration of Schools and Housing Post-Parents Involved, 29 LAW \& INEQ. 149, 160 (2011) (arguing that "metropolitan integration is one of the most effective strategies known to reduce white flight and to make schools and neighborhoods more racially stable"). 
all remedies seen in practice, metropolitan, or interdistrict, plans have been better at desegregation than mere city-wide plans. ${ }^{172}$

\section{School District Boundaries Are Not Sacred}

The boundaries that confine students to particular school districts, however, are a political oddity that have garnered more of a permanent feel than they deserve. ${ }^{173}$ The Court in Milliken, for example, considered such boundaries untouchable. As Chief Justice Warren Burger wrote, "the [notion] that school district lines may be casually ignored or treated as administrative convenience is contrary to the history of public education in our country." 174 Since those words, district boundaries have been justified as "the inevitable function of physical geography and a commitment to democratic norms, freedom of association, private property rights, and freedom of contract." ${ }^{175}$ Boundaries are viewed as "immutable, rather than contingent, features of the legal and political landscape." 176

The absolute nature of school district boundaries, however, is largely a political fiction. ${ }^{177}$ The law is clear that school districts, perhaps even more than other local governmental agencies, "are but creatures of the state." ${ }^{178}$ State government, not local authorities, therefore, have the power to "create, alter, reorganize, or destroy school districts." ${ }^{179}$ As Justice Marshall pointed

\footnotetext{
${ }^{172}$ See powell, supra note 47, at 759-60 ("Metropolitan-wide school integration strategies, across municipal lines, have been more successful at promoting and maintaining a greater level of integration than city-wide approaches."). One such example is the metropolitan-wide school district Louisville, Kentucky, which the U.S. Department of Education recently called "one of the most diverse districts in the nation." U.S. DEP'T OF EDUC., IMPROVING Outcomes For All Students: Strategies AND Considerations To InCREASE STUdent Diversity , 17 (2017) [hereinafter DEP'T OF EDUC. DIVERSITY REPORT]. Parents in the district have been highly supportive of the district and continued desegregation efforts. As of 2011 , over $90 \%$ of parents believed diverse schools have educational benefits for students. Id.; see also Kimberly Quick \& Rebecca Damante, Louisville, Kentucky: A Reflection on School Integration, THE CENTURY FOUNDATION (September 2016), https://tcf.org/content/report/louisvillekentucky-reflection-school-integration/ (describing Louisville as "one of the most integrated districts in the nation"). ${ }^{173}$ See generally Aaron J. Saiger, The School District Boundary Problem, 42 URB. LAW. 495, 499-507 (2010) (detailing the origins and dimensions of the problems caused by school district boundaries). As Professor Saiger points out, "Legal rules that define school district boundaries as semipermeable, allowing some things to freely pass across them while others are restricted or blocked, have made boundaries--the lines that separate districts on the map--one of the great engines of educational inequity in America." Id. at 499.

${ }^{174}$ Milliken, 418 U.S. at 741 . Justice Marshall, on the other hand, rejected district boundaries as nothing more than "fences thrown up" to block access to educational opportunity. Id. at 783 (Marshall, J., dissenting).

${ }^{175}$ Richard Thompson Ford, Beyond Borders: A Partial Response to Richard Briffault, 48 STAN. L. REV. 1173, 1176 (1996).

${ }^{176}$ See Saiger, supra note 173, at 507 (likening the perception of school district boundaries to "rivers or streams").

${ }^{177}$ As one example of the random nature of school district boundaries, Justice Marshall pointed out that "contrary to the Court's implication, there is little or no relationship between school districts and local political units." Milliken, 418 U.S. at 795 (Marshall, J., dissenting). As Marshall explained:
}

To take the 85 outlying local school districts in the Detroit metropolitan area as examples, 17 districts lie in two counties, two in three counties. One district serves five municipalities; other suburban municipalities are fragmented into as many as six school districts. Nor is there any apparent state policy with regard to the size of school districts, as they now range from 2,000 to 285,000 students.

$I d$. The pattern that Marshall identified in Michigan is not uniform throughout the United States, however, as some school districts are more contiguous with other political boundaries. See Nadav Shoked, An American Oddity: The Low, History, and Toll of the School District, 111 Nw. U. L. REV. 945, 958-59 (2017) (finding that almost half of all states have district boundaries that do not match other local government boundary lines).

${ }^{178}$ See Saiger, supra note 173, at 511 ("The blackest of black-letter doctrine insists that school districts, like other local governments, are but creatures of the state.").

${ }^{179}$ Richard Briffault, The Role of Local Control in School Finance Reform, 24 CoNN. L. REV. 773, 780 (1992). 
out in his dissent in Milliken, school districts are entirely subordinate to state governments, who have ultimate authority over education policy. ${ }^{180}$ As state courts have long recognized, the authority to draw or change school district boundaries lies with states, not local school districts. ${ }^{181}$

The unique requirements of state government are important with respect to who has the power over school district boundaries. All fifty states have some form of an education clause in their state constitutions, ${ }^{182}$ a recognition that is unique to education. ${ }^{183}$ Many states already consider education a fundamental right. ${ }^{184}$ Twenty-two states have interpreted their education clause to confer an affirmative obligation on the state to provide an adequate education. ${ }^{185}$ Without exception, the right to education under state constitutional law has always required at least a minimal guarantee of quality of education. ${ }^{186}$

${ }^{180}$ As Justice Marshall pointed out in his dissent in Milliken:

The majority's emphasis on local governmental control and local autonomy of school districts in Michigan will come as a surprise to those with any familiarity with that State's system of education. School districts are not separate and distinct sovereign entities under Michigan law, but rather are auxiliaries of the State, subject to its absolute power. The courts of the State have repeatedly emphasized that education in Michigan is not a local governmental concern, but a state function.

Id. at 794 (Marshall, J., dissenting) (internal citation omitted); see also Briffault, supra note 177, at 780 ("IV]irtually every state has created some form of state institutional bureaucracy for public education, typically a state board of education; most states also have a state-level chief education officer. This structure allows for formal state administrative monitoring of, and policymaking for, local school districts.").

${ }^{181}$ See, e.g., Norton v. Lakeside Special Sch. Dist., 133 S.W. 184, 185 (Ark. 1910) ("The [1]egislature is primarily vested with the power to create school districts, and it may create or abolish a school district, or change the boundaries of those established for any reason that may be satisfactory to it."); Attorney Gen. ex. rel. Kies v. Lowrey, 92 N.W. 289, 291 (Mich. 1902) ("It does not seem to be denied that the legislature may change the boundaries of districts. That has been too often done to admit of question."); Town of Lisbon v. Lisbon Vill. Dist., 183 A.2d 250, 253 (N.H. 1962) (finding that state legislatures have the power to create local governments and also to "modify or divide them in such manner as to meet the public exigencies"). Prior to Milliken, that was the understanding of the Supreme Court, too. See, e.g., Hunter v. City of Pittsburgh, 207 U.S. 161, 178-79 (1907) ("The state, therefore, at its pleasure, may . . expand or contract the territorial area, unite the whole or a part of it with another municipality, repeal the charter and destroy the corporation.").

${ }^{182}$ See Jeffrey M. Shaman, The Evolution of Equality in State Constitutional Law, 34 RuTGERS L. J. 1013, $1087 \mathbf{n}$. 532 (2003) (listing all fifty state education clauses).

${ }^{183}$ As the Supreme Court of Vermont put it, for example, "[o]nly one governmental service - public education - has ever been accorded constitutional status." Brigham v. State, 692 A.2d 384, 392 (Vt. 1997); see also Claremont Sch. Dist. v. Governor, 703 A.2d 1353, 1356 (N.H. 1997) ("[P]ublic education differs from all other services of the State. No other governmental service plays such a seminal role in developing and maintaining a citizenry."); Lake View Sch. Dist. No. 25 v. Huckabee, 91 S.W.3d 472, 492 (Ark. 2002) (stating that "education has been of paramount concern to the citizens of this state since the state's inception is beyond dispute. It is safe to say that no program of state government takes precedence over it."); McDuffy v. Sec'y of Exec. Office of Educ., 615 N.E.2d 516, 548 (Mass. 1993) ("The crux of the Commonwealth's duty lies in its obligation to educate all of its children."). The Supreme Court also recognizes the state's special role in education. See Wisconsin v. Yoder, 406 U.S. 205, 213 (1972) ("Providing public schools ranks at the very apex of the function of a State").

${ }^{184}$ See Ken Gormley, Education as a Fundamental Right: Building a New Paradigm, 2 F. ON PUB. POL'Y 207, 219 (2006) ("The highest courts of at least fourteen states, at one time or another, have declared that education is a fundamental right under their state constitutions.") (listing the states at footnote 63).

${ }^{185}$ Anne Gordon, California Constitutional Law: The Right to an Adequate Education, 67 Hastings L.J. 323, 35152 (2016). Importantly, "only a minority of states have found that their education clauses confer no substantive right." Id. at 352 .

${ }^{186}$ See id. at 352-53 ("Where a state's high court has found a right to education, none has found that right to exist without a guarantee of quality."). 
Given the impact of school district boundaries on the educational opportunities of lowincome students of color in central city districts, one of the top priorities for states in meeting their constitutional obligations would be to redraw district boundaries and remove the "fences" that Marshall worried about in Milliken ${ }^{187}$ Confining students to segregated districts is becoming all too similar to the sort of separate education that Brown prohibited. ${ }^{188}$ Instead of separate school systems based on race within a single district, schools are segregated across district lines - urban districts segregated from suburban counterparts. ${ }^{189}$ Consolidation, for example, of city and suburban districts would simply extend a trend that had been in motion for the last several decades. Between 1900 and 1970, for example, 90\% of American school districts were eliminated through consolidation. ${ }^{190}$

\section{B. Beyond Race: Proxies and Broader Diversity}

\section{The Impact of Parents Involved}

After years of scaling back the Court's ability to desegregate schools, ${ }^{191}$ the Supreme Court imposed significant limitations on what school districts could do voluntarily to address school segregation. In Parents Involved, the Court considered whether the Seattle and Louisville school districts' voluntary desegregation plans could use a student's race in making studentassignment plans. ${ }^{192}$ In striking down both desegregation plans, the plurality found neither the design nor the operation of the desegregation plans were sufficiently narrowly tailored because they were tied to "specific racial demographics, rather than to any pedagogic concept of the level of diversity needed to obtain the asserted educational benefits." 193 Chief Justice John Roberts" majority opinion emphasized that strict scrutiny is the standard of review "when the government distributes burdens or benefits on the basis of individual racial classifications." 194

${ }^{187}$ Daniel Kiel, The Enduring Power of Milliken's Fences, 45 URB. LAW. 137, 138 (2013) (“[D]istrict boundaries made sacrosanct by Milliken represent a major impediment to confronting the persistent gap in educational opportunity.").

${ }^{188}$ See $i d$. at 144 ("Although the separation is geographic rather than racial, the correlation between race, geography, and socioeconomic status results in an educational landscape in metropolitan areas that looks disturbingly similar to the world before Brown."). To the extent that the issue of intent is relevant, there is plenty of evidence to suggest that "the geographic boundaries that define school districts are the product of local government law structures that foster residential segregation and exclusion based on race and class." Erika K. Wilson, Toward a Theory of Equitable Federated Regionalism in Public Education, 61 UCLA L. REV. 1416, 1418 (2014). "As a result, race, class, and geography intersect to shape the opportunities available to students and to exclude poor minority students from access to high-quality schools." Id. at 1418-19.

${ }^{189}$ See Kiel, supra note 185, at 144 (explaining that "just as the law had once mandated separation based upon race, so too does contemporary district sovereignty, enshrined in law, mandate separation based upon geography").

${ }^{190}$ Saiger, supra note 173 , at 510 . The fewer than 15,000 school districts that existed in 1970 "are the successors to approximately 200,000 school districts that existed in $1900 . " \mathrm{Id}$.

${ }^{191}$ See Hilbert, supra note 48, at 10-15 (discussing the many cases the Court decided while unraveling desegregation remedies).

192 See Parents Involved, 551 U.S. at 710-11 (plurality opinion) (stating the issue presented to the Court). Parents Involved is a complex, fractured decision. Importantly, as the Departments of Justice and Education have explained, "The portions of the plurality opinion that Justice Kennedy joined constitute the opinion of the Court." DEP'TS OF JustiCE \& OF EduC. GuIDANCE, supra note 28, at 3.; see also Erica Frankenberg et al., The Future is Now: Legal and Policy Options for Racially Integrated Education, 88 N.C. L. REV. 713, 715 n.8 (2010) (sorting out the various opinions and which ones are controlling for which pieces of the decision).

${ }^{193}$ Parents' Involved, 551 U.S. at 726 (plurality opinion).

${ }^{194} \mathrm{Id}$. at 720 (plurality opinion). For Justice Breyer it was "a cruel distortion of history ... to equate the plight" of African Americans forced to attend segregated schools and whites "forced" to attend desegregated ones. Parents Involved, 551 U.S. at 867 (Breyer, J., dissenting). As the Justice made clear, the cost in applying a "state-mandated 
While it is not clear how many districts had plans similar to those struck down by Parents Involved, ${ }^{195}$ studies have shown that numerous school districts withdrew from diversity plans as a result of the Court's decision. ${ }^{196}$ In the wake of the decision, districts largely adopted more race-neutral policies and "even drop[ped] the pursuit of diversity altogether," because districts believed that race-conscious options were not permissible after Parents Involved ${ }^{197}$ Regardless of the number of districts affected, there is no questions that in comparison to the landscape before the Court's decision, districts' responses to Parents Involved expressed "a diminution in the use of race" by school districts in efforts to combat school segregation. ${ }^{198}$

Other branches of the federal government were undermining desegregation efforts at the same time. For example, the Office of Civil Rights in the Department of Education ("OCR") under the Bush Administration actively discouraged districts from pursuing desegregation plans. ${ }^{199}$ After the Parents Involved decision, the OCR issued a "Dear Colleague" letter that misinterpreted the decision "as antithetical to the very goal of integrated education, and warned districts against the pursuit of any type of voluntary, race-conscious student assignment strategies." 200 Parents Involved and the OCR sent a clear message that swayed school districts from doing anything meaningful about segregation. ${ }^{201}$

\section{Segregation Jujitsu: Using Neighborhood Characteristics to Promote Diversity}

racial label ... does not approach, in degree or in kind, the terrible harms of slavery, the resulting caste system, and 80 years of legal racial segregation." Id. (citations omitted).

195 See Chemerinsky, supra note 17, at 639 (noting that estimates of the number of estimates on the actual number of districts "fatally similar to those of Louisville and Jefferson County that were struck down by Parents Involved vary considerably from more than 1,000 to possibly less than ten").

${ }^{196}$ See Frankenberg, supra note 16, at 678 (reviewing "broad-based and more in-depth studies" to conclude that "there is evidence suggesting a chilling effect of the Parents Involved decision"). Of course, many inside and outside of the system had long given up on pursuing desegregation. See Ryan, supra note 72, at 132 ("Advocates and reformers have turned their attention elsewhere, and today battles are waged in legislatures and in state courts over school funding, school choice, standards and testing, and access to preschool.").

${ }^{197}$ See Frankenberg, supra note 16, at 704 (finding that such reactions "may be influenced at least in part by the mixed message of Parents Involved as to whether diversity is a goal worth pursuing"). In interviews, various district officials explained "that [they] thought that they could not consider race when asked why such policies had been adopted." Id. at 704.

${ }^{198} \mathrm{Id}$. at 699 .

${ }^{199}$ See Chemerinsky, supra note 17, at 642 (explaining how "the efforts of the Office of Civil Rights in the Department of Education under the Bush Administration only served to make matters worse in discouraging school systems from adopting voluntary desegregation plan").

${ }^{200}$ Genevieve Siegel-Hawley, The Integration Report, Issue 23, INTEGRATION ReP. (Jan. 13, 2010), http:// theintegrationreport.wordpress.com/2010/01/13/issue-23/ ("The goals of racially integrated education, according to the Bush-era Education Department, was to be realized without direct consideration of race.").

${ }^{201}$ As one conservative activist put it: "[S]chool-board members now know that, when their counterparts in Seattle and Louisville used race-based student assignments, they enmeshed their respective school districts in years of litigation, ultimately losing and ultimately requiring them to pay, not just their own lawyers, but the opposing side's lawyers as well. 'No thanks,' other school boards will say." Roger Clegg, A Good--If Mixed Bag, NATIONALREVIEWONLINE (July 5, 2007), http://article.nationalreview.com/320765/a-good----if-mixed-bag-/rogerclegg. Costs in such cases can be staggering. Even before its case was concluded the Lower Merion school district spent well over one million dollars in legal fees defending this case, and they ended up winning. See Richard Ilgenfritz, Legal Fees Mount for LMSD, MAIN LiNE TiMES (Aug. 12, 2010), http://www.mainlinemedianews.com/articles/2010/08/12/main_line_times/news/doc4c62bd6f7bdac 151351309.txt. 
But the Court's decision in Parents Involved is not nearly as damaging as many feared ${ }^{202}$ Justice Kennedy's controlling opinion did not rule out the use of race-conscious desegregation policies. ${ }^{203}$ Just as the Third Circuit would later rule in Lower Merion ${ }^{204}$ Justice Kennedy wrote that explicit inclusion of race is permissible when using race in a general way, rather than at an individual level ${ }^{205}$ In his controlling concurrence in Parents Involved, Justice Kennedy considered the kind of plan used by the Lower Merion school district as presumptively valid, clarifying that "[s]chool boards may pursue the goal of bringing together students of diverse backgrounds and races through other means, including ... drawing attendance zones with general recognition of the demographics of neighborhoods."206

Strategies along the lines of Berkeley and Lower Merion, therefore, could leverage existing housing segregation to promote school integration, without running afoul of Parents Involved. ${ }^{207}$ In fact, a recent study concluded that "neighborhood-level demographic and

\footnotetext{
${ }^{202}$ See Frankenberg \& Le, supra note 71, at 1021 ("Certainly, the decision prohibits some of the most direct means school districts may use to attack the problem and therefore makes things a great deal more challenging. But it also allows some room, albeit not much, for play in the joints.").

${ }^{203}$ This was also the interpretation of the U.S. Departments of Justice and Education in their joint analysis of the decision. See Dep'TS Of JustiCe \& Of Educ. GuidanCE, supra note 28, at 4 ("Justice Kennedy refused to rule out approaches that in appropriate circumstances take account of the race of individual students in school assignment."). Justice Kennedy went even further to state that in certain circumstances school districts can consider the race of individual students so long as they consider other characteristics, too. See Parents Involved, 551 U.S. at 79 (stating that a school district, if necessary, can employ a "more nuanced individual evaluation of school needs and student characteristics that might include race as a component"). Such an individualized approach would be informed by the narrow tailoring analysis set forth in Grutter, "though of course the criteria relevant to student placement would differ based on the age of the students, the needs of the parents, and the role of the schools." Id.

${ }^{204}$ Doe ex rel. Doe v. Lower Merion Sch. Dist., 665 F.3d 524, 545 (3d Cir. 2011) (approving attendance zones based on the racial composition of neighborhoods because such a plan is only "assigning students to schools based only on the geographical areas in which they live").

${ }^{205}$ See, e.g., Parents Involved, 551 U.S. at 788-89 (Kennedy, J., concurring) (stating that school districts "are free to devise race-conscious measures to address the problem [of segregation] in a general way and without treating each student in different fashion solely on the basis of a systematic, individual typing by race").

${ }^{206}$ Parents Involved, 551 U.S. at 789 (Kennedy, J., concurring). Interestingly, the Third Circuit in Lower Merion considered Justice Kennedy's guidance as mere "dicta." Lower Merion, 665 F.3d at 544 n.32; but see United States v. Alamance-Burlington Bd. of Educ., 640 F.Supp.2d 670, 683 n.5 (M.D.N.C. 2009) ("[T]his Court has relied on the concurring opinion of Justice Kennedy, as discussed above, in setting out the framework governing the School System going forward."); Hart v. Cmty. Sch. Bd. of Brooklyn, 536 F. Supp.2d 274, 282 (E.D.N.Y. 2008) ("[T] he view of Justice Kennedy in [Parents Involved], which represents the applicable approach under Marks, [is] the guiding standard on the use of race as one of a number of appropriate admissions factors."); N.N. ex. rel. v. Madison Metro. Sch. Dist., 670 F.Supp.2d. 927, 937 (W.D. Wis. 2009) ("Because no single opinion in [Parents Involved] garnered a majority of the Court, Justice Kennedy's opinion is controlling, at least to the extent it represents the narrowest grounds for invalidating the two plans. Both Grutter and Justice Kennedy emphasized that race may be an appropriate part of a diversity plan when race is considered as only one factor among many." (internal quotation marks and citations omitted)); see also Ryan, supra note 72, at 137 (explaining that Justice Kennedy's concurrence is controlling because he only concurs in part of the plurality's opinion and the four dissenters "would apply looser criteria to assess voluntary integration plans than would Justice Kennedy"); see also DEP'TS OF JUSTICE \& OF EDUC. GUIDANCE, supra note 28 , at 5 ("Thus, although there was no single majority opinion on this point, Parents Involved demonstrates that a majority of the Supreme Court would be 'unlikely' to apply strict scrutiny to generalized considerations of race that do not take account of the race of individual students.").

${ }^{207}$ See Robinson, supra note 95, at 339-40 (2009) ("School districts also may seek to promote diversity and avoid racial isolation by drawing attendance-zone boundaries so as to bring together students from a racially mixed group of neighborhoods and to address segregated housing patterns, which represent the primary cause of segregated schools.").
} 
socioeconomic characteristics are relatively accurate predictors of student race/ethnicity."208 Relying on such geographic integration plans could actually "increase diversity in schools." ${ }^{209}$ In addition to a combination of race and socioeconomic status of students in residential areas, ${ }^{210}$ other viable "diversity factors include academic achievement, educational attainment, and linguistic status."211

\section{Promoting Racial Diversity through Race-Neutral Means Alone}

Of course, even plans that completely avoid explicit racial categorizations may still promote important diversity. Because of the close connection between certain race-neutral characteristics and race, using such characteristics as proxies could result in the reduction of racial segregation. Socioeconomic status is one obvious potential proxy. ${ }^{212}$ The academic benefits for low-income students from socioeconomic diversity is clear. ${ }^{213}$ Reliance on socioeconomic status, on its own, however, may fail to reach entrenched racial inequality. Poverty alone cannot explain patterns of racial segregation. ${ }^{214}$ Not surprisingly, "research suggests that socioeconomic plans are not as successful as race-conscious plans in creating racially diverse schools." 215

\section{Beyond Demographics: Integration Requires More Than Just Numbers}

\footnotetext{
${ }^{208}$ Richards et al., supra note 118 , at 93 . The study conducted "an empirical test of Berkeley-style geographic integration plans in the nation's 10 largest metropolitan school districts, investigating whether such models have the potential to help districts wishing to integrate their schools in the wake of the Parents Involved decision." Id. at 93. ${ }^{209}$ See id. ("Our findings indicate that geographic integration plans would be especially effective at integrating elementary schools, small schools, and schools in relatively more segregated districts with less diverse neighborhoods.").

210 See Frankenberg, supra note 16, at 699 (finding that the most common factor is eligibility for free or reducedprice lunch, which is a binary measure above or below a threshold that is $185 \%$ of the poverty line).

${ }^{211} I d$. Indeed, the St. Paul school district in Minnesota reserves enrollment spots in their low-poverty schools for students who live in designated areas across the district using poverty, language status, and test score results. Mila Koumpilova, St. Paul district: 'High-need' areas among changes planned to school choice, ST. PAUL PIONEER PRESS (November 10, 2015, 5:16 am), http:/www.twincities.com/2012/12/01/st-paul-district-high-need-areasamong-changes-planned-to-school-choice/; see also TEFERA ET AL., supra note 38, at 30 (listing the five factors that Montclair, New Jersey uses in assigning students, including (1) neighborhood racial demographics, (2) percentage of free and reduced-price lunch students, (3) household poverty rates, (4) median household income, and (5) parental education levels).

${ }^{212}$ Kristi L. Bowman, A New Strategy for Pursuing Racial and Ethnic Equity in Public Schools, 1 DUKE F. FOR L. \& SOC. CHANGE 47, 55-56 (2009) (discussing how racial and socioeconomic segregation "occur together shockingly often. In general, the more black and brown a school's population is, the more likely it is that students in that school are predominantly poor.").

${ }^{213}$ See, e.g., James E. Ryan, Sheff, Segregation, and School Finance Litigation, 74 N.Y.U. L. REV. 529, 557-58 (1999) (collecting studies and concluding that "[a] fairly large and consistent body of research indicates that integration along socioeconomic lines is one of the most effective educational strategies for improving the achievement of disadvantaged students").

${ }^{214}$ Alex M. Johnson, Jr., How Race and Poverty Intersect to Prevent Integration: Destabilizing Race as a Vehicle to Integrate Neighborhoods, 143 U. PA. L. REV. 1595, 1657 (1995). Poverty alone cannot explain why African Americans and whites live in separate neighborhoods "because of the significant overlap of white and Black poor." Id.

${ }^{215}$ Frankenberg, supra note 16, at 704 (denoting that because socioeconomic plans alone are not as successful, "there could be negative consequences for racial integration efforts to adopting race-neutral plans"). For example, when examining neighborhood-based diversity programs, like Berkeley's, residents' socioeconomic status was less predictive of student race than the percentage of neighborhood students of color. Richards et al., supra note 118, at 85.
} 


\section{Integration vs. Desegregation}

When addressing school segregation, definitions matter. "Desegregation" has largely been the removal of the formal structures constructed by policies of "segregation," while "integration" means something far more expansive. ${ }^{216}$ Using Dr. King's descriptions, desegregation is understood as the process of undoing segregation, but only in the limited sense of removing barriers. ${ }^{217}$ In practice, this has meant mostly that desegregation is about numeric balance by putting students together in the same buildings, and nothing more. ${ }^{218}$

The result has been a policy more like assimilation than the transformation originally envisioned by the architects who litigated Brown. ${ }^{219}$ In many desegregation plans, the goal appeared to focus merely on having students of color "blending in" with the white majority. ${ }^{220} \mathrm{In}$ such an arrangement, the impact on students of color felt more like subjugation than the overthrow of white supremacy. ${ }^{221}$ Without anything more than just moving students around, there has been no impact on the "qualitative experience of educating" students of different backgrounds, resulting in the subjecting of students of color to "assimilationist pressures."222

Dr. King drew an important distinction between desegregation and integration. ${ }^{223}$ According to King, desegregation was merely "physical proximity without spiritual affinity."224

${ }^{216}$ In the words of Dr. King:

The word segregation represents a system that is prohibitive; it denies the Negro equal access to schools, parks, restaurants, libraries and the like. Desegregation is eliminative and negative, for it simply removes these legal and social prohibitions. Integration is creative, and is therefore more profound and far-reaching than desegregation. Integration is the positive acceptance of desegregation and the welcomed participation of Negroes in the total range of human activities.

KING, supra note 23, at 118.

${ }_{217}$ See Michelle Adams, Shifting Sands: The Jurisprudence of Integration Past, Present, and Future, 47 How. L.J. 795,797 (2004) (defining desegregation as "the active disestablishment of a segregated hierarchy, structure, or entity").

${ }^{218}$ See powell, supra note 47 , at 782-83 ("Desegregation has traditionally meant either, in the narrow sense, removing formal legal barriers, or simply placing students in physical proximity to one another.").

${ }^{219}$ See Garda, supra note 22, at 7 ("[T]hey believed in the intrinsic values and benefits of integration. They viewed education as inherently intertwined with society and hoped to engineer a society that learned and worked together, not one that co-existed in parallel worlds.") (citing MARK V. TUSHNET, THE NAACP's LEGAL STRATEGY AGAINST SEGREGATED EDUCATION, 1925-50 at xi (1987)).

${ }^{220}$ Edwards, supra note 66, at 960.

${ }^{221}$ The purpose of Brown and subsequent desegregation court orders was to "dismantle the system of oppression and legally sanctioned apartheid in this country." The Honorable George B. Daniels, \& Rachel Pereira, May It Please the Court: Federal Courts and School Desegregation Post-Parents Involved, 17 U. PA. J. CONST. L. 625, 626 (2015); see also john a. powell \& Stephen Menendian, Parents Involved: The Mantle of Brown, The Shadow of Plessy, 46 U. LOUISVILLE L. REV. 631, 673 (2008) (describing Brown as "part of the overthrow of a caste system"). Instead, "desegregation assimilate[d] minorities into the mainstream." john a. powell, A New Theory of Integrated Education: True Integration, in SCHOOL DeSEGREGATION: MusT THE SOUTH TuRn BACK? 281, 298 (John Charles Boger \& Gary Orfield eds., 2005).

${ }^{222}$ Paradise, supra note 61, at 447-48. During the height of desegregation, for example, "it was not uncommon for schools undergoing desegregation to conduct business as usual and to ignore the issue of race." Id. at 448; see also WELLS ET AL., supra note 61, at 141 ("The lack of a dialogue about race combined with the maintenance of a traditional Eurocentric curriculum became a de facto assimilationist project in these schools.").

${ }^{223}$ As Dr. King put it, "our ultimate goal is integration, and that desegregation is only a first step on the road to the good society." KING, supra note 23, at 118; see also Adams, supra note 50, at 18 ("Dr. King championed integration on the theory that the eradication of artificial barriers to communication and the formation of interrelationships would both facilitate black equality and allow everyone to better appreciate a common, shared humanity."). 
A school can be desegregated, for example, but not integrated. ${ }^{225}$ Students can be placed together without any impact on how they think about one another. ${ }^{226}$ As a result, desegregation on its own could have "little or no effect on the racial norms that govern the particular situation or society as a whole." 227

In contrast to desegregation, and its "stagnant equality of sameness," King defined integration as "the positive acceptance of desegregation and the welcomed participation of Negroes into the total range of human activities."228 Whereas assimilation is "the process whereby 'a minority group gradually adopts the customs and attitudes of the prevailing culture,", ${ }^{229}$ Dr. King understood integration as "genuine intergroup, interpersonal doing." 230 Others have carried forward King's understanding of integration as qualitatively different from desegregation. ${ }^{231}$ Professor Michelle Adams has defined "integration" as "the bringing together of racial or ethnic groups for the purpose of fostering and facilitating equality, at least with respect to the terms and conditions upon which the groups might interact." ${ }^{232}$ Professor john powell clarifies that "integration is not simply a goal in terms of the schools in which students learn as a static site, but requires a transformation of the setting in which the identities of students are formed and form others." 233

${ }^{224}$ See KING, supra note 23, at 118 ("We do not have to look very far to see the pernicious effects of a desegregated society that is not integrated ... where elbows are together and hearts are apart.").

${ }_{225}$ See Adams, supra note 217 , at 797 ("[A] school or institution might well be 'desegregated' in the sense that it is no longer actively engaging in activities that bring about segregation, but that does not mean that the institution is truly integrated.") (quoting powell, supra note 221, at 671).

${ }^{226}$ Scholars have noted that interracial interaction, in and of itself, is often not enough to change racial attitudes. See, e.g., J. Eric Oliver, The Paradoxes Of Integration: Race, Neighborhood, AND Civil Life In MultiethniC AMERICA 7 (2012) ("According to social psychologists and social capital theorists, interracial proximity is not sufficient for reducing racial hostility; rather, if people are to overcome their racial animosities toward other groups, they must do so through contact in very specific circumstances (that is, all parties must be of equal status and work together towards a shared goal)."); LEONARD STEINHORN \& BARBARA DIGGS-BROWN, BY THE COLOR OF OUR SKIN: THE ILLUSION OF INTEGRATION AND THE REALITY OF RACE 5 (1999) (positing that "it is entirely possible to desegregate without integrating - for blacks and whites to attend the same schools without ever learning much about each other or becoming friends .... Desegregation may unlock doors, but integration is supposed to open minds").

${ }^{227}$ Bridgeman, supra note 64 , at 717 . Without more than just the mixing of students from different background, there is no "alteration of white supremacist notions of race, because there is nothing in the integrated interaction or situation to upset the norms." Id. at 718 .

${ }^{228}$ KING, supra note 23, at 118 ; see also Adams, supra note 50, at 17 ("'[I]ntegration entertains the hope that the association of members of different races within a context of social equality might benefit all by destroying stereotypes, suspicion and mistrust."). This vision of integration "champions the creation of new communal affiliations in which interracial affections are a positive good." Id. at 18. (citing Randall Kennedy, On Racial Integration, 43 DISSENT 3 (1996)).

${ }^{229}$ Edwards, supra note 66 , at 645 .

${ }^{230} \mathrm{KING}$, supra note 23, at 118. "Thus, for King, unlike desegregation, integration excludes subordination and assimilation and welcomes difference." Paradise, supra note 61, at 447.

${ }^{231}$ Paradise, supra note 61, at 446-47 (describing how he and other scholars apply King's definitions and distinguish between desegregation and integration).

${ }^{232}$ Adams, supra note 217, at 797; see also powell, supra note 47, at 783 ("Integration, as a solution to segregation, has a broader meaning; it refers to community-wide efforts to create a more inclusive society, where individuals and groups have opportunities to participate equally in their communities. Inclusion gives us the tools to build democratic communities, with the ability to approach complex issues from a multitude of perspectives.").

${ }^{233}$ powell, supra note 18, at 681; see also Paradise, supra note 61, at 447 ("[F]ormally all-white schools . . often operated on a colorblind model. In practice, this meant that there was often very little, if any, effort to foster crossracial understanding and appreciation of African-American heritage and history. As a result, a culture of privileging whiteness and subordinating blackness often continued unchallenged."). 


\section{Integration Requires More Than Balancing the Numbers}

To achieve actual integration, rather than the mere balancing of students, school districts must go beyond the demographic composition of its schools. ${ }^{234}$ Rather than exclusive reliance on the numbers, administrators must create a "more inclusive educational system." ${ }^{235}$ These systems would require a more holistic set of policies, rather than just demographic targets. ${ }^{236}$ This would include "different types of educational reforms that implicate everything from district restructuring to refashioning classroom dynamics. ${ }^{237}$ As many have previously suggested, such integrative remedies could include curricular reform and innovations, professional training and development for teachers and administrators, and non-academic programming designed to increase meaningful cross-racial interaction among students and teachers. ${ }^{238}$ At the same time, educational systems should institute reforms that address "accountability measures, tracking, discipline policies, and the school environment." 239 To create a more inclusive learning environment, "remedies must be as complex, long-term, and broad as the problems they seek to address." 240

Almost 15 years after Brown, the Supreme Court created a more precise list of what was required for effective desegregation. ${ }^{241}$ The Court declared that Brown required the dismantling of the "dual systems" of public education in which there were identifiable white and African American schools. ${ }^{242}$ The Court found that school districts have a duty "to create a unitary, nonracial system."243 The Court in Green pointed to six areas where school systems should be made nonracial and unitary: students, faculty, staff, facilities, transportation, and extracurricular activities. ${ }^{244}$ In determining whether the vestiges of past discrimination have been eliminated to

\footnotetext{
${ }^{234}$ Districts must also be careful to look beyond just the buildings and avoid re-segregating students after they enter an otherwise numerically diverse school. In too many schools, "racially segregated classes make it unlikely that children of different races will have meaningful interaction during the school day." Days, supra note 25, at 55; see generally supra notes 64-65 and accompanying text (discussing intra-school segregation).

${ }_{235}$ john a. powell \& Marguerite L. Spencer, Brown is not Brown and Educational Reform is Not Reform If Integration Is Not a Goal, 28 N.Y.U. REV. L. \& SOC. CHANGE 343, 350 (2003).

${ }^{236}$ Indeed, "[ $\left.\mathrm{t}\right]$ he failure to incorporate a holistic set of desegregative measures, beyond the simple racial balancing of schools, allowed for a system that, left unfettered, actually served to reinforce a system of devaluing AfricanAmerican students." Epperson, supra note 25, at 205-06.

${ }^{237}$ powell \& Spencer, supra note 235 , at 350.

${ }^{238}$ See, e.g., Epperson, supra note 25 , at 205 . For example, one recent study found that culturally relevant pedagogy showed significant benefits to "historically marginalized students," including increased attendance, GPA, and credits earned. Thomas Dee \& Emily Penner, The Causal Effects of Cultural Relevance: Evidence from an Ethnic Studies Curriculum," 54 AMERICAN EDUC. RESEARCH JOURNAL, n.1, 128-29 (2017).

${ }^{239}$ See powell \& Spencer, supra note 235 , at 350 n.56 (citing studies). Suspension disparities are particularly stark between white students and African American students. See U.S. Department of Education, Office for Civil Rights, 2013-14 Civil Rights Data Collection: A First Look, at 3 (Revised October 28, 2016), available at:

https://www2.ed.gov/about/offices/list/ocr/docs/2013-14-first-look.pdf (finding that African American students are nearly four times as likely as white students to receive one or more out-of-school suspensions).

${ }^{240}$ Epperson, supra note 25, at 178.

${ }^{241}$ See Green, 391 U.S. at 437-38 (clarifying that school boards have an "affirmative duty to take whatever steps might be necessary to convert to a unitary system in which racial discrimination would be eliminated root and branch").

${ }^{242} I d$. at 435 .

${ }^{243}$ Id. at 440 (quoting Bowman v. Cty. Sch. Bd. of Charles City Cty., 382 F.2d 326, 333 (C.A.4th Cir. 1967).

${ }^{244} \mathrm{Id}$. at 435; see also Swann, 402 U.S. at 18 ("In Green, we pointed out that existing policy and practice with regard to faculty, staff, transportation, extra-curricular activities, and facilities" are "among the most important
} 
the extent practicable, lower courts "should look not only at student assignments, but 'to every facet of school operations." "245

\section{A Place to Start: Integrating the Teaching Ranks}

The lack of diversity of teachers in American schools is one such area of school operations in particular need of attention. Nationwide, although over $50 \%$ of the public school student population are students of color, teachers of color comprise only $18 \%$ of the teaching workforce. ${ }^{246}$ This discrepancy may be growing as schools become more diverse. ${ }^{247}$ As a result, the vast majority of students of color are instructed only by teachers of a difference race, and white students are instructed almost exclusively by white teachers. ${ }^{248}$

The lack of diversity in the teaching ranks goes back all the way to the early days immediately after the Brown decision and Massive Resistance, when school districts conducted wholesale firings and demotions of African American teachers and administrators. ${ }^{249}$ According to one report, "by 1972, more than 41,600 African-American educators in the southern states had been displaced or lost their jobs. ${ }^{250}$ Moreover, those remaining African American teachers who

indicia of a segregated system.") (citations omitted). As the Court noted, "[i]ndependent of student assignment, where it is possible to identify a 'white school' or a 'Negro school' simply by reference to the racial composition of teachers and staff, the quality of school buildings and equipment, or the organization of sports activities, a prima facie case of violation of substantive constitutional rights under the Equal Protection Clause is shown." Id. at 18. ${ }^{245}$ Bd. of Educ. of Okla. City Pub. Sch., 498 U.S. at 250. (quoting Green, 391 U.S. at 435).

${ }^{246}$ U.S. DePAR TMENT OF EDUCATION, THE STATE OF RACIAL DiVERSITY IN THE EDUCATOR WORKFORCE 1 (2016) [hereafter DEP'T OF EDUC., STATE OF WORKFORCE DiverSity]. African American males continue to be the most underrepresented group, relative to the number of similar race students, at a mere $2 \%$ of the teaching force. Rod Taylor, Teacher Diversity Failing in American Schools, 33 No. 24 EMP. AlERT NL 3, 1 (November 24, 2016). 247 "According to a PEW Research Center study, currently more than half of children under five in America" are children of color. See, e.g., Taylor, supra note 246 , at 1.

${ }^{248}$ Overall, roughly $80 \%$ of African American elementary-school children are taught by teachers of another race. Alia Wong, Why Are There So Few Black Children in Gifted Programs, THE ATLANTiC (Jan. 19, 2016). In lowpoverty schools that are predominantly white, $82 \%$ of teachers were white. DEP'T Of EDUC., STATE OF WORKFORCE DIVERSITY, supra note 246 , at 2 . White teachers often try to leave heavily segregated schools that are predominantly students of color. "According to studies that investigate teacher turnover in segregated schools, race is the driving factor in predicting teacher mobility, more so than working conditions or student poverty." See Wendy Parker, Desegregating Teachers, 86 WASH. U. L. REV. 1, 36 n.130 (2008) (discussing evidence suggesting that white teachers who decide to leave schools that are heavily students of color are reacting to race, not poverty or achievement).

${ }^{249}$ See Epperson, supra note 25, at 206 (describing the "surreptitious strategies used by intransigent Southern school districts to purge African American educators from public schools"). This included:

(1) firing African American teachers for exercising their political rights or for joining the NAACP; (2) administering reprisals to those African American teachers who spoke out in favor of complying with desegregative orders; (3) firing thousands of African American teachers before districts actually desegregated; (4) abolishing tenure laws where there were large numbers of black educators, thus giving administrators the right to fire teachers without cause; (5) dismissing teachers even with tenure laws in place by hiring them outside of their certified field and then firing them for incompetence; and (6) retaining white faculty while demoting or dismissing black faculty.

Mary Hatwood Futrell, The Impact of the Brown Decision on African American Educators, in the Unfinished Agenda of Brown v. Board of Education 86-87 (Editors of Black Issues in Higher Educ. et al. eds., 2004).

${ }^{250}$ Id. at 206-207; See, e.g., Mary Hatwood Futrell, The Impact of the Brown Decision on African American Educators, in THE UNFINISHED AGENDA OF BROWN V. BOARD OF EDUCATION 79, 86-87 (Editors of BLACK ISSUES IN HIGHER EDUC. et al. eds., 2004) (citing Samuel B. Ethridge, Impact of the 1954 Brown v. Topeka Board of Education Decision on Black Educators, 4 NEGRo EdUC. REV. 30 (1979) ("More than half of all black public school administrators were demoted or dismissed.")). 
moved to previously all-white schools "usually found themselves in hostile environments where some white teachers refused to even speak to them or questioned the validity of their teaching credentials." ${ }^{251}$ And for the white teachers, there was little professional development "to help acculturate black and white students or teachers into the newly desegregated schools."252

Perhaps even more concerning, the disproportionately low number of teachers of color may be significantly impacting the academic outcomes of students of color. According to a recent report by the United States Department of Education, "racial diversity among teachers can provide significant benefits to students." ${ }^{253}$ Multiple studies show that students of color have improved academic outcomes when in learning environments with more diverse teaching ranks. ${ }^{254}$ A more diverse teaching force provides students of color with more role models and other critical support for their learning and development. ${ }^{255}$ Teachers of color also help white students in their racial attitudes and beliefs. ${ }^{256}$

In addition, a lack of teacher diversity may also contribute to the substantial race disparities that exist in the receipt of gifted education services in American schools. ${ }^{257}$ The

\author{
${ }^{251} I d$. \\ ${ }^{252} I d$. at 207. \\ ${ }^{253}$ DeP'T OF Educ., STATE OF WORKFORCE Diversity, supra note 246, at 1. As the report clarifies, teacher \\ diversity benefits "all students," not just students of color. \\ 254 See Ana M. Villegas \& Jacqueline Irvine, Diversifying the Teaching Force: An Examination of Major
} Arguments, 42 URB. REV. 175, 180 (2010) (reviewing studies that "suggest that students of color accrue academic benefits when taught by a same-race teacher or when exposed to a teaching force (at the school or district level) that is racially/ethnically representative of the student population"); DEP'T OF EDUC., STATE OF WORKFORCE DIVERSITY, supra note 246, at 2 ("[T] eachers of color contribute to improved academic outcomes" for students of color); Jane G. Coggshall et al., Enhancing Educators' Capacity to Stop the School-To-Prison Pipeline, 51 FAM. CT. REV. 435 , 440 (2013) (finding that "although the exact mechanisms are not known," exposure to more teachers of color boosts academic achievement for students of color).

${ }^{255}$ See DEP'T OF EDUC., STATE OF WORKFORCE DIVERSITY, supra note 246, at 2 (reporting that "teachers of color are more likely to (1) have higher expectations of students of color (as measured by higher numbers of referrals to gifted programs); (2) confront issues of racism; (3) serve as advocates and cultural brokers; and (4) develop more trusting relationships with students, particularly those with whom they share a cultural background"); see also Villegas \& Irvine, supra note 254 at 177 ("As role models, teachers of color are believed to boost the self worth of students of color, motivate this population of students to strive for social success, and decrease the sense of alienation many students of color experience in schools and classrooms."); Coggshall, supra note 254 , at 440 ("This mismatch between educators' backgrounds and the backgrounds of the students they work with is problematic because a lack of understanding and separation from the out-of-school lives of students and their families can hinder educators' capacity to establish positive, caring relationships with their students, to have abiding high expectations for students of color and to implement culturally relevant practices.").

${ }^{256}$ See Villegas \& Irvine, supra note 254, at 177 (finding that "ongoing interactions with teachers of color give White students opportunities to dispel myths of racial inferiority they might have internalized about people of color from their socialization outside schools"); see also DEP'T OF EDUC., STATE OF WORKFORCE DIVERSITY, supra note 246, at 1 ("Teachers of color are positive role models for all students in breaking down negative stereotypes and preparing students to live and work in a multiracial society.").

${ }^{257}$ Jason A. Grissom \& Christopher Redding, Discretion and Disproportionality: Explaining the Underrepresentation of High-Achieving Students of Color in Gifted Programs, 2 AM. ED. RES. AsSOCIATION JOURNAL 1 (2016) (on file with author) ("Data from the Office for Civil Rights (OCR) at the U.S. Department of Education reveal that as of 2009 , African American students constitute $16.7 \%$ of the student population but just $9.8 \%$ of students in gifted programs. Similarly, [Latinx] students constitute $22.3 \%$ of students but only $15.4 \%$ of students receiving gifted services." These disparities are particularly concerning "because studies have linked participation in gifted programs to positive future outcomes, including increased academic performance and improvements in motivation, self-efficacy, engagement with learning, nonacademic self-concept, and overall stress." (citation omitted)). 
disparity is so stark that the gap between races in gifted services contributes to the intra-school segregation in otherwise diverse schools. ${ }^{258} \mathrm{~A}$ recent study finds that part of the disparity can be explained by the race of the teacher. ${ }^{259}$ As the study reports, "because the process often begins with teacher referral, classroom teachers can play a gatekeeping role in gifted assignments." 260 African American students in classes with non-African American teachers were found to be "systematically less likely to receive gifted services in subsequent years, particularly in reading." 261 The race of the teacher impacts other aspects of the educational system, as well, such as parent involvement. ${ }^{262}$ Unfortunately, efforts at recruiting additional teachers of color have been largely unsuccessful. ${ }^{263}$

\section{Beyond Education: The Connection between Housing and Schools}

\section{Integrating Schools May Require Reforming Housing Policy}

One other critical dimension to truly integrating our schools requires going even beyond education. School integration may not be possible through education policies alone. The legacies of segregation persist on several levels. ${ }^{264}$ This means that addressing segregation, even just in schools, will require "multiple approaches to breaking down segregation in our society."265

Housing may be the most important of the broader issues related to school segregation. The relationship between where people live and where they choose to send their children to school is clear to most people. ${ }^{266}$ Families choose which neighborhood to live in often based on

\footnotetext{
${ }^{258} I d$.

${ }^{259} I d$. at 16 ("We emphasize, however, that teacher-student race congruence only partially explains the apparent underassignment of Black students to gifted programs that remains even after student test scores; other background characteristics, such as SES; and classroom and school characteristics are taken into account.").

${ }^{260} \mathrm{Id}$. at 1 .

261 Id. at 14.

${ }^{262}$ See id. at 4 (explaining that students of color "may be more willing to engage with" the school system "in beneficial ways because of the presence of bureaucrats [of color] with whom they can more easily communicate or identify." The presence of teachers of color may also help parents of color feel more comfortable advocating for their children's needs or making it more likely that they tap into school information networks. In the context of a gifted assignment, a parent of color may feel more at ease requesting from a teacher of color "that his or her child be screened or seek out advice or information from that teacher about how to obtain gifted services." (citations omitted)).

${ }^{263}$ Part of the problem is the lack of teachers of color in the system now. See Coggshall et al., supra note 254 , at 440 ("In a vicious cycle, the lack of teacher role models that look like these students and the lack of inspiring teachers who are well prepared to meet the needs of diverse learners also play important roles in the lack of interest among students of color to enter teaching and subsequently school leadership."); see also Villegas \& Irvine, supra note 254 , at 177 ("In separate investigations, teacher candidates of color reported that serving as a role model for students of color was the primary reason for their wanting to teach."); but see Taylor, supra note 246 , at 1 (describing a few efforts that have shown some success in recruiting more teachers of color, such as Boston's High School-to-Teacher Project and other "homegrown" programs).

${ }^{264}$ See, e.g., Jeffrey J. Wallace, Ideology vs. Reality: The Myth of Equal Opportunity in a Color Blind Society, 36 AKRON L. REV. 693, 714 (2003) (detailing segregation in "our churches, schools, social clubs, and neighborhoods" and stating that "Sunday morning between 9:00 a.m. and 2:00 p.m. is considered the most segregated time in America").

${ }^{265}$ powell, supra note 47, at 754; see id. ("Focusing on desegregating schools alone cannot produce lasting results and ultimately does not integrate society or increase and enhance participation in our democracy.").

${ }^{266} \mathrm{Id}$. It is clear to the Supreme Court as well. See, e.g., Swann, 402 U.S. at 20-21 ("People gravitate toward school facilities, just as schools are located in response to the needs of people.").
} 
the schools available. ${ }^{267}$ Because of the close connection between where people live and the available schools, districts become "pivotal players in the politics of place, and their decisions regarding the future of public schooling have the capacity, even if unwittingly, to shape America's residential landscape."268 For example, more often than not, "the public schools considered the best are in middle-class and upper middle-class neighborhoods." 269

2. The Link between Housing and Education \& the Role of the Court

The Supreme Court recognized this connection, too. In Swann, the Court asserted that the long-term consequences of decisions over the location of new and to-be-closed schools impacts more than just education and "will be far reaching." 270 According to the Court, the location of schools can "influence the patterns of residential development of a metropolitan area and have important impact on the composition of inner-city neighborhoods. ${ }^{271}$ For example, the Court concluded that decisions to build new schools in far-flung white suburbs, while closing those schools closer to the center of the inner-city that "appeared likely to become racially mixed ... does more than simply influence the short-run composition of the student body of a new school." 272 Such decisions "may well promote segregated residential patterns which, when combined with 'neighborhood zoning,' further lock the school system into the mold of separation of the races." 273

As the Court concluded, this link has played a critical role in maintaining the segregation of our schools. ${ }^{274}$ Housing and schools have been "central factors in creating our segregated society." 275 Like America's schools, housing in the United States is also substantially segregated by both race and income. ${ }^{276}$ Despite the clear relationship between housing and schools, policy

\footnotetext{
${ }^{267}$ See Wayne Batchis, Urban Sprawl and the Constitution: Educational Inequality as an Impetus to Low Density Living, 42 URB. LAw. 95, 95 (2010) ("The quality of educational opportunity offered to residents of a particular community consistently ranks as one of the most important variables in determining where Americans choose to reside, especially among those with school-aged children.").

${ }^{268}$ Id. at 110; see also DEP'T OF EDUC. DIVERSITY REPORT, supra note 172, at 6 ("Because school demographics are closely associated with residential diversity patterns, optimal planning for school diversity usually includes collaboration with housing agencies.") (citing U.S. Department of Housing and Urban Development, U.S. Department of Education, and U.S. Department of Transportation, Dear Colleague Letter (June 2016)).

${ }^{269}$ powell, supra note 47 , at 756 .

${ }^{270}$ Swann, 402 U.S. at 20-21.

${ }^{271}$ Id ; see also Batchis, supra note 267, at 110 ("The Court's reasoning [in Swann] was also informed by its realization that public schools and residential patterns are intimately intertwined.").

${ }^{272}$ Swann, 402 U.S. at 20-21.

${ }^{273}$ Id. at 21; see also Adams v. United States, 620 F.2d 1277, 1291 (8th Cir. 1980) (noting that the public perception of a school's racial identity is an influential factor in shaping community residential patterns); United States v. Bd. of Sch. Comm'rs, 573 F.2d 400, 407 (7th Cir. 1978) ("It is generally agreed that racial residential patterns are reflected in the student composition of an area's public schools and that racial segregation in public schools and racial segregation in housing are integrally interrelated.").

${ }^{274}$ See Keyes v. Sch. Dist. No. 1, Denver, Colo., 413 U.S. 189, 201-02 (1973) (stating that "earmarking schools according to their racial composition ... may have a profound reciprocal effect upon the racial compositions of residential neighborhoods within a metropolitan area").

${ }^{275}$ powell, supra note 47 , at 755 .

${ }^{276}$ Charles M. Lamb et al., HMDA, Housing Segregation, and Racial Disparities in Mortgage Lending, 12 STAN. J. C.R. \& C.L. 249, 250 (2016) (reviewing research and concluding that "housing segregation and discrimination persist in America"). While residential segregation has slowly declined since the late 1960s, African American to white residential segregation continues to be "very high." JOHN R. LOGAN \& BRIAN J. STULTS, THE PERSISTENCE OF Segregation In The Metropolis: New Findings From The 2010 Census 4 (2011), http://www.s4.brown.edu/us2010/Data/Report/report2.pdf. As researchers John Logan and Brian Stults wrote, "[t]he
} 
makers in both housing and education fields have failed to link these policies to address this reality. ${ }^{277}$

Just like the policy-makers, courts have failed to connect these two policies when addressing school segregation. Such failure has created "missed opportunities" to deal with school segregation. ${ }^{278}$ Courts too often have blamed segregation on merely the "normal pattern of human migration."279 The Court has also denied the existence of a causal link between school segregation and white flight, attributing the phenomenon to demographic changes outside the scope of government control (and hence outside a court's remedial reach). ${ }^{280}$ In Missouri v. Jenkins, for example, while the members of the Court and the parties agreed that the Kansas City schools and neighborhoods are segregated, the majority of the Court refused to examine seriously the causes of the city's severe segregation. ${ }^{281}$

\section{Housing Segregation is No Accident}

Housing segregation, however, is not just the result of random chance or individual actions. Geographic segregation has been the result of specific government actions for decades. ${ }^{282}$ Discrimination in the housing market has contributed strongly to this pattern. ${ }^{283}$ Low-

basic message here is that whites live in neighborhoods with low minority representation. Blacks and Hispanics live in neighborhoods with high minority representation, and relatively few white neighbors." $I d$. at 3 . Setting aside implications for education policy, residential segregation on its own has harmful impacts on residents trapped in low-income communities. See Douglas S. Massey \& Jonathan Tannen, A Research Note on Trends in Black Hypersegregation, 52 DEMOGRAPHY 1025, 1027 (2015),

https://www.ncbi.nlm.nih.gov/pmc/articles/PMC4886656/pdf/nihms787708.pdf ("Subsequent research has confirmed the close connection between black segregation and spatially concentrated disadvantage, as well as the strong negative influence of concentrated disadvantage on black life chances." (citation omitted)).

${ }_{277}$ powell, supra note 47 , at 756 ; see id. at 756 ("A generous reading of this failure is that policy makers, isolated within their areas of expertise, are not sufficiently aware of the relationship between housing and education."); see also Batchis, supra note 267, at 96 ("Scholars and policy experts in the fields of education and housing tend to work in isolation from one another, focusing on their respective areas of expertise and unlikely to see the fundamental connections between these issues.").

${ }^{278}$ See Epperson, supra note 25, at 208 (criticizing the courts for "missed opportunities to address the vestiges of segregation by treating intersecting issues, such as the relationship between persistent residential segregation and the continued racial segregation in public schools, as non-justiciable").

${ }^{279}$ See, e.g., Pasadena City Bd. of Educ. v. Spangle, 427 U.S. 424, 436 (1976) (concluding that segregation in the local schools had "apparently resulted from people randomly moving into, out of, and around the ... area. This quite normal pattern of human migration resulted in some changes in the demographics of Pasadena's residential patterns, with resultant shifts in the racial makeup of some of the schools.").

${ }^{280}$ See Jenkins, 515 U.S. at 96 ('The record here does not support the district court's reliance on 'white flight' as a justification for a permissible expansion of its intradistrict remedial authority through its pursuit of desegregative attractiveness."); see id. at 121 (Thomas, J., concurring) ("[N]eutral policies, such as local school assignments, do not offend the Constitution when individual private choices concerning work or residence produce schools with high black populations."). An earlier Supreme Court, however, had expressly reserved the question of "whether a showing that school segregation is a consequence of other types of state action, without any discriminatory action by the school authorities, is a constitutional violation requiring remedial action by a school desegregation decree." Swann, 402 U.S. at 23.

${ }^{281}$ See powell, supra note 47 , at 751 ("The majority opinion never discussed the history of housing discrimination, lending bias, public housing construction, federal home mortgage loan programs, or other contributors to racial segregation .. . [which] all helped create segregation in Kansas City, just as they have in most other major American metropolitan communities.").

${ }^{282}$ See Douglas S. Massey \& Nancy A. Denton, American Apartheid: Segregation And The Making Of THE UNDERCLASS 51 (1993) (detailing "the extent to which the federal government became involved in perpetuating racial segregation"). 
income housing projects have been disproportionately sited in the most racially segregated neighborhoods. ${ }^{284}$ Early decisions by the federal government set in motion the patterns of our residential segregation. ${ }^{285}$

Addressing school segregation, therefore, requires addressing housing segregation, as well. The two policies must be linked, ${ }^{286}$ and the two solutions must be pursued together. ${ }^{287}$ Successfully integrated districts have more integrated housing, while integrating housing may lead to substantial reductions in school segregation. ${ }^{288}$ Even more importantly, student

${ }^{283}$ See id. at 109-10 (discussing several studies that "document and quantify the link between discrimination, prejudice, and segregation"); M. Orfield, supra note 171, at 162 ("There was clear national and local evidence that minority parents, even those with middle-class incomes, experienced housing discrimination in terms of steering, mortgage lending discrimination, and disparate treatment by white sellers and rental agents, which prevented them from having the same housing choices as whites of similar income and education during this period."); see also Juan F. Perea, Doctrines of Delusion: How the History of the G.I. Bill and Other Inconvenient Truths Undermine the Supreme Court's Affirmative Action Jurisprudence, 75 U. PITT. L. REV. 583, 596 (2014) ("The federal government, through the Federal Housing Administration (FHA) and the Home Owners Loan Corporation (HOLC), had a direct hand in this housing discrimination."). Government action set the stage for private housing discrimination. See, e.g., $i d$. at 598 ("Federal underwriting guidelines thus directed and enabled race discrimination by private banks and realestate brokers.").

${ }^{284} \mathrm{M}$. Orfield, supra note 171 , at 162.

${ }^{285}$ See generally Perea, supra note 283 , at 597-98 (documenting the federal role and concluding that "[t]he FHA actively promoted segregated neighborhoods"). For example, the FHA's Underwriting Manual provides evidence of the federal government's race discrimination. Until 1948, the underwriting manual "explicitly identified Black Americans as unreliable and undesirable buyers." DESMOND King, SEPARATE AND UNEQUAL 191 (1995). The extensive role played by the FHA in encouraging race discrimination in mortgage lending was explained decades ago by Charles Abrams:

From its inception FHA set itself up as the protector of the all-white neighborhood. It sent its agents into the field to keep Negroes and other minorities from buying homes in white neighborhoods. It exerted pressure against builders who dared to build for minorities, and against lenders willing to lend on mortgages. This official agency not only kept Negroes in their place but pointed at Chinese, Mexicans, American Indians, and other minorities as well. It not only insisted on social and racial "homogeneity" in all its projects as the price of insurance but became the vanguard of white supremacy and racial purity-in the North as well as the South.

Charles Abrams, ForbidDEn Neighbors 229-30 (1955); see also KenNeth T. JACKSOn, CRABgrass Frontier: THE Suburbanization Of THE United STATES 209 (1985) (quoting the FHA Commissioner in 1948 stating that the FHA does not insure housing projects that are integrated because "such projects would probably in a short period of time become all-Negro or all-white").

${ }^{286}$ See powell, supra note 47 , at 754 ("The answer, it appears, is in linking educational integration policies to housing. Linking policies designed to integrate schools with housing provides a path to building integrated communities.").

${ }^{287}$ See powell \& Spencer, supra note 235, at 351 ("[W]e must pursue educational and housing solutions together"). Of course, addressing other major institutions would be helpful to alleviating school segregation, too. See id. at 35051 (identifying other issues that would help such as equalizing wealth and opportunity, employment, transportation, and health care opportunities).

${ }^{288}$ See M. Orfield, supra note 171, at 173 ("Places that have done a good job integrating their schools have more integrated housing markets and places that integrate their housing markets have more integrated schools. There could be great synergies if these problems were addressed together."); see also Myron Orfield \& Will Stancil, Why Are the Twin Cities So Segregated?, 43 Mitchell Hamline L. Rev. 1, 7 (2017) ("A proactive approach to housing integration, in which subsidized housing units are distributed evenly across the region and Section 8 rental vouchers beneficiaries are distributed in proportion to regional population, would . . . account for $80 \%$ of the student moves necessary to create a fully integrated regional school system ...."). 
achievement is closely linked to where they live and the composition of their neighborhoods. ${ }^{289}$

Housing integration can have a significant impact on the educational outcomes of lowincome students of color, in particular. In one recent study conducted in Montgomery County, access to diverse schools through housing integration worked substantially better to improve academic achievement than well-funded school-based interventions. In Montgomery County, a portion of its low-income students attend low-poverty, diverse schools through an inclusionary zoning policy, ${ }^{290}$ while other low-income students attend well-funded, but higher-poverty, segregated schools. ${ }^{291}$ The results from the seven-year study confirm that children who attended diverse schools through the inclusionary zoning policy significantly out-performed their peers. ${ }^{292}$ The study also found that just living in integrated neighborhoods improves educational achievement, independent of school quality. ${ }^{293}$ Promoting housing integration, alongside school integration efforts, must be a priority. ${ }^{294}$

${ }^{289}$ Sheryll Cashin, Place, Not Race: Affirmative Action and the Geography of Educational Opportunity, 47 U. MiCH. J.L. REFORM 935, 942 (2014) ("A large body of social science research suggests that where one lives can directly affect . . low-income children's school performance.").

${ }^{290}$ Montgomery County "operates the nation's oldest and by far the largest inclusionary zoning program." HEATHER Schwartz, CENTURY Found., Housing PoliCy Is SCHOOL POLICY: ECONOMICALly INTEGRATIVE Housing Promotes ACADEMIC SuCCESS In MONTGOMERY COUNTY, MARYLAND 4 (2010), available at https://tcf.org/assets/downloads/tcf-Schwartz.pdf. Under the program, real estate developers set aside a portion of the homes they build to be rented or sold at below-market prices. $I d$.

${ }^{291}$ In this respect, Montgomery County provided a good comparison of whether integrated schools can outperform well-funded but segregated schools in educating low-income students. Importantly, the public housing authority randomly assigns families to their housing, so a comparison between the two sets of families is not subject to selection bias. In essence, children are "assigned randomly to their elementary schools via the public housing placement process." Id. at 5.

${ }^{292}$ See id. at 6 ("After five to seven years, students in public housing who were randomly assigned to low-poverty elementary schools significantly outperformed their peers in public housing who attended moderate-poverty schools in both math and reading."); Kahlenberg, supra note 101, at 4-5 (discussing the Montgomery County project and concluding that the "results were unmistakable: low-income students attending more-affluent elementary schools (and living in more affluent neighborhoods) significantly outperformed low-income elementary students who attend higher-poverty schools with state-of-the-art interventions"); Michael R. Hilton, Literacy, Poverty, and Brain Development: Toward a New, Place-Based Educational Intervention, 17 RICH. J.L. \& PUB. INT. 623,658 (2014) (concluding that results from Montgomery County "suggest that providing low-wealth students in high-poverty schools with compensatory resources in the form of school-based interventions is not as effective at raising student achievement as housing policy changes that encourage economic integration”); Cashin, supra note 289, at 942 (reporting that that Montgomery County study "demonstrated greatly improved achievement among black and Latino public housing residents when they moved to a middle-class neighborhood and attended middle-class schools"); see also id. at 943 (noting that "[a] control group of children of color who remained in public housing and were assigned to high poverty schools with extra resources were not as successful as those allowed to integrate into higher opportunity schools").

${ }^{293}$ Schwartz, supra note 290 , at 8 . Living in low-poverty neighborhoods in and of itself helps improve school outcomes for low-income students. But "school-based economic integration had about twice as large an effect as neighborhood-based economic integration on low-income children's academic performance." Id.

294 See Hilton, supra note 292, at 658 (suggesting that a "housing program targeting areas of concentrated disadvantage and working toward resettling resident families in more affluent neighborhoods could have a potentially game-changing impact"). Of course, housing integration has numerous other benefits, in addition to its positive impact on educational outcomes. See Schwartz, supra note 290, at 35-36 (detailing the many benefits to Montgomery County beyond educational outcomes of its inclusionary housing policy). 


\section{IV: CONCLUSION}

America's schools are still segregated largely because previous desegregation efforts were too limited, focusing only on the numeric balance of students and failing to address larger policy issues, such as housing patterns and teacher diversity. The Court's withdrawal from desegregation efforts has been part of the problem, but how desegregation has been constructed and conceptualized over multiple generations has had a larger impact on the prevalence and permanency of segregation in public education.

Desegregation has always meant something short of the promise of integrated schools. Because desegregated schools are measured entirely by the mere demographic mix of students, they were never fully integrated. Integration, as compared to desegregation, is about much more than numbers. Martin Luther King cautioned that we must adhere to the purpose of integration and not just conform to the "letter of the law." in the student body; it means inclusive curriculum and a diverse teaching force. Schools in districts confined to the boundaries of central cities are not usually integrated, because integration needs metropolitan-wide options untethered to historical patterns of segregation. Actual integration reaches past education itself, linking housing and education policy together. Finally, integration must also mean more than racial diversity, since the Supreme Court's recent restrictive decision in Parents Involved; it requires broader measures, such as income, location, and neighborhood characteristics.

Of course, for the many flaws in previous efforts, desegregation did attain important achievements. School segregation remains, but many of its artifices are long gone. More importantly, perhaps, are the lessons drawn from the power of diversity to improve academic outcomes and repair racial attitudes. Imperfect as it was, desegregation did lead to the consensus that even limited diversity works to improve the education and life outcomes of all students; an opportunity to build on this legacy exists for future generations.

Despite this progress, past approaches to ending segregation, however, were largely incomplete and left the racial hierarchy in place. More comprehensive measures are required to fulfill the promise of $\mathrm{Brown}^{296}$ and to transform our classrooms into truly inclusive learning environments. Through actual integration, rather than traditional desegregation, school districts can move beyond mere demographics and prepare all students for their important roles as citizens in our diverse democracy. ${ }^{297}$

\footnotetext{
${ }^{295}$ KING, supra note 23, at 118.

${ }^{296}$ See Parents Involved, 551 U.S. at 867-68 (Breyer, J., dissenting) (explaining that the promise of Brown "was about the nature of democracy that must work for all Americans").

${ }^{297}$ See Milliken v. Bradley, 418 U.S. 717, 783 (1974) (Marshall, J., dissenting) ("[U]nless our children begin to learn together, there is little hope that our people will ever learn to live together.").
} 


\title{
Mitchell Hamline Open Access
}

Mitchell Hamline Open Access is the digital archive of Mitchell Hamline School of Law. Its mission is to preserve and provide access to our scholarly activities, for the benefit of researchers and members of the legal community.

Mitchell Hamline Open Access is a service of the Warren E. Burger Library.

open.mitchellhamline.edu

\author{
$\mathrm{MH}$ \\ MITCHELL | HAMLINE \\ School of Law \\ (C) Mitchell Hamline School of Law \\ 875 Summit Avenue, Saint Paul, MN 55105 \\ mitchellhamline.edu
}

